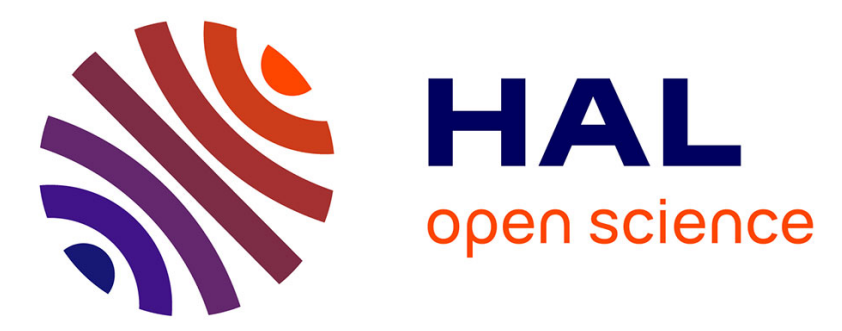

\title{
Chemical Heterogeneity in Inbred European Population of the Invasive Hornet Vespa velutina nigrithorax
}

\author{
Jeremy Gevar, J.-P. Christidès, A.-G. Bagnères, Éric Darrouzet
}

\section{To cite this version:}

Jeremy Gevar, J.-P. Christidès, A.-G. Bagnères, Éric Darrouzet. Chemical Heterogeneity in Inbred European Population of the Invasive Hornet Vespa velutina nigrithorax. Journal of Chemical Ecology, 2017, 43 (8), pp.763-777. 10.1007/s10886-017-0874-4 . hal-02874908

\section{HAL Id: hal-02874908 https://hal.science/hal-02874908}

Submitted on 12 Nov 2020

HAL is a multi-disciplinary open access archive for the deposit and dissemination of scientific research documents, whether they are published or not. The documents may come from teaching and research institutions in France or abroad, or from public or private research centers.
L'archive ouverte pluridisciplinaire HAL, est destinée au dépôt et à la diffusion de documents scientifiques de niveau recherche, publiés ou non, émanant des établissements d'enseignement et de recherche français ou étrangers, des laboratoires publics ou privés. 
Chemical heterogeneity in inbred European population of the invasive hornet Vespa velutina nigrithorax

J. Gévar, A.-G. Bagnères, J.-P. Christidès, E. Darrouzet**

IRBI, UMR CNRS 7261, University François Rabelais of Tours, Parc de Grandmont, 37200

Tours, France.

*Corresponding author: eric.darrouzet@univ-tours.fr

\section{Key words}

Invasive species, Inbreeding, Cuticular hydrocarbons, Queen pheromone, Yellow-legged hornet.

\section{Abstract}

Invasive social insect populations that have been introduced to a new environment through a limited number of introduction events generally exhibit reduced variability in their chemical signatures (cuticular hydrocarbons) compared to native populations of the same species. The reduced variability in these major recognition cues could be caused by a reduction of genetic diversity due to a genetic bottleneck. This hypothesis was tested in an inbred European population of the invasive hornet Vespa velutina nigrithorax. Our results show that, in spite of the limited amount of genetic diversity present in the European population, the chemical signatures of individuals were highly heterogeneous according to their caste, sex, and colony origin. In queens, some specific saturated and unsaturated hydrocarbons were identified. These results suggest that epigenetic and/or environmental factors could play a role in modifying cuticular hydrocarbon profiles in this introduced hornet population despite the observed reduction of genetic diversity.

\section{Introduction}

The insect cuticle is covered by a thin lipid layer, which largely consists of cuticular hydrocarbons (CHCs). Because of their chemical properties, $\mathrm{CHCs}$ primarily act to limit insect water loss through the creation of a surface barrier. In addition, they also serve as contact pheromones, i.e. recognition cues, for inter- and intraspecific recognition among insects. The $\mathrm{CHC}$ profile of an individual serves as a personalized chemical signature (Blomquist and Bagnères 2010; Ginzel and Blomquist 2016). Several studies have demonstrated a strong link between the social behavior of insects and their cuticular signatures (Bagnères et al. 1991; Howard and Blomquist 2005; Leconte and Hefetz 2008). 
CHCs are mainly involved in the recognition of nestmates (Howard and Blomquist 2005; van Zweden and D'Ettorre 2010), castes (Bagnères et al. 1998; Kaib et al. 2000; Smith and Taylor 1990), and worker's tasks (Rahman et al 2016). Therefore, chemical signatures can vary, and the degree of variation depends on a wide range of endogenous factors, such as the endocrine system or enzymes (Darrouzet et al. 2014b; Fan et al. 2004; Lengyel et al. 2007), and exogenous factors, such as climate and season (Bagnères et al. 1990), diet (Liang and Silverman 2000), parasitism (Bagnères et al. 1996; Lebreton et al. 2010; LeConte et al. 2015), or time (Bagnères et al. 2011; Lebreton et al. 2009). The relative importance of these factors varies among species (VanderMeer and Morel 1998). However, CHC profiles are modified not only by the social or biotic environment but are also under genetic control in both social and solitary insects (Bonavita-Cougourdan et al. 1996; Dronnet et al. 2006; Etges et al. 2009; Thomas and Simmons 2008; Vauchot et al. 1996). Consequently, variation in CHC profiles has been used to identify species (Bagnères and Wicker-Thomas 2010) and to differentiate populations (Bonelli et al. 2015; Nowbahari et al. 1990). This type of chemotaxonomy, i.e. the use of chemical compounds, has been productively used in numerous insect species. However, less attention has been paid to the extent or function of chemical variation within invasive species, which in their introduced ranges often experience habitats and species interactions that are strikingly different from those of their native environments (Perdereau et al. 2010).

Native to China, the invasive yellow-legged hornet, Vespa velutina nigrithorax, was accidentally introduced to southwestern France around 2004, probably in imported ceramic pottery (Haxaire et al. 2006). The species has successfully expanded its range to cover more than $75 \%$ of France, and is currently colonizing neighboring countries (Spain, Portugal, Italy, Belgium, Germany, and England) (Darrouzet et al. 2014a; Goldarazena et al. 2015; Monceau et al. 2013; Robinet et al. 2017). Thus far, V. velutina invasion in France has two main negative impacts. First, the species preys on several insect and arthropod taxa, thus potentially affecting local biodiversity. In particular, V. velutina is a predator of the domestic honeybee, Apis mellifera, and could induce economic losses via the destruction of bee colonies (Darrouzet et al. 2014a; Monceau et al. 2013). Second, the species presents a risk to human health. Accidents have occurred, some fatal, when people have inadvertently approached the hornet's nests (de Haro et al. 2010).

New colonies of $V$. velutina are established in the spring by mated queens, after the overwintering period. Colonies first pass through a period in which an increasingly large number of workers are produced in order to ensure colony growth, and then produce sexual 
individuals (males and gynes) at the end of the summer (Monceau et al. 2013; Rome et al. 2015). These reproductive individuals emerge between late August and November. After reproductive flights, the gynes disperse and the males die. However, Darrouzet et al. (2015) showed that several colonies produced diploid males all throughout the colony life. As authors explained, this result strongly suggests the occurrence of inbreeding in this species in its invaded range (Europe). This hypothesis was supported by genetic analyses based on a combination of mitochondrial and nuclear markers (Arca et al. 2015; Takeuchi et al. 2017). The authors suggested that the yellow-legged hornet population in France was derived from a single introduction event, and they showed evidence of a strong founder effect. Thus the French populations sampled in that study suffered a notable loss of genetic diversity compared to native populations in China.

In the present study, we analyzed the chemical signature of the invasive hornet $V$. velutina nigrithorax in France, i.e. in an inbreeding context, to test whether this reduced genetic diversity translates into homogeneity in the insects' chemical signatures, as has been reported for other invasive social insect species (Linepithema humile: Brandt et al. 2009; Wasmannia auropunctata: Errard et al. 2005; Reticulitermes flavipes: Perdereau et al. 2010).

\section{Materials and Methods}

\section{Insect collection}

Hornet colonies were collected in 16 different locations in the Centre-Val-de-Loire region in France (Table 1). In each colony, individuals from each caste and sex present (workers, gynes, males, and queens when possible) were randomly selected, with a maximum of 10 per caste. Insects were weighed and stored at $-20^{\circ} \mathrm{C}$ before being further analyzed.

\section{Cuticular hydrocarbon (CHC) analyses}

CHCs were collected by plunging each hornet in $1 \mathrm{ml}$ pentane for 2 x $1 \mathrm{~min}$ (vortex). A 500$\mu 1$ aliquot of pentane extract was transferred to a new tube. Immediately prior to analyses, 10 $\mu \mathrm{L}$ of $n$-C20 (n-eicosane; concentration $10^{-3} \mathrm{~g} / \mathrm{ml}$ ) was added to each tube as an internal standard. Then, $2-\mu \mathrm{L}$ samples were analyzed using gas chromatography (GC) in a CPG Agilent Technologies 7820A GC System equipped with a flame-ionization detector (FID) and a capillary column (HP-5 Agilent Technology, Santa Clara, USA; 30 m x 0.32 mm x 0.25 $\mu \mathrm{m})$ using helium as a carrier gas $(1.7 \mathrm{ml} / \mathrm{min})$. The following temperature program was used: a first temperature ramp from 50 to $200^{\circ} \mathrm{C}$ at $8^{\circ} \mathrm{C} / \mathrm{min}$, a second temperature ramp from 200 to $315^{\circ} \mathrm{C}$ at $5^{\circ} \mathrm{C} / \mathrm{min}$, and a 5 -min final hold at $315^{\circ} \mathrm{C}$. 
To identify the compounds (CHCs) in the chemical signatures according to caste and sex (workers, gynes, and males), CHC extracts were pooled from nine random hornets, each from a different randomly selected colony (Table 1S). Workers and gynes were discriminated according to their size and weight (Rome et al. 2015). CHCs from five random queens were also extracted and pooled. The samples were dried, then stored at $-20^{\circ} \mathrm{C}$. Before being analyzed, $300 \mu \mathrm{l}$ of pentane was added to each, with the internal standard as in the previous analysis. To determine which compounds were present, we used an Agilent Technologies 7000C GC/MS Triple Quad with a 7890B GC System equipped with the same column as above; we also used the same temperature program as above. Compounds were identified following Blomquist (2010) and using standard $n$-alkanes.

To characterize the $\mathrm{CHC}$ profiles, the areas of the main peaks were determined using ChemStation software (Agilent Technologies), and the relative proportions of each peak were calculated as described in Bagnères et al. (1990).

\section{Calculations and statistical analyses}

To determine whether we could use chemical (CHC) profiles to discriminate among colonies and/or among individuals within a colony on the basis of caste and sex, we performed multivariate principal component analyses (PCAs) using the R 2.14.1 software.

Differences in $\mathrm{CHC}$ composition among and within colonies were quantified using the Nei distance (Dronnet et al., 2006; Nowbahari et al 1990). The dissimilarity matrix, which included all possible types of pairs (intra-caste, inter-caste within a colony, and inter-colony within a caste), was constructed from the previously calculated mean relative areas of cuticular hydrocarbon peaks and were analyzed with a Kruskal-Wallis test using R 2.14.1.

For each individual, the quantity of each $\mathrm{CHC}$ was estimated with the following formula: $\mathrm{Qi}=\left(\mathrm{Q}_{\mathrm{C} 20} \mathrm{X} \mathrm{xi}\right) /\left(\mathrm{x}_{\mathrm{C} 20} \mathrm{i}\right)$. The quantity of each $\mathrm{CHC}$ was then divided by the mass of the individual to obtain the per-gram quantity of each compound.

\section{Results}

Analyses of $\mathrm{CHCs}$

Out of the peaks detected by GC, only the 75 most stable peaks (of which four were queenspecific) in individuals in each group were retained and used in our statistical analyses. Among the identified CHCs, which ranged in chain length from 21 to 35 carbon atoms, we found $n$-alkanes (13.48\%, 12 compounds), mono- and dimethyl-alkanes $(57.30 \%, 51$ compounds), alkenes (17.98\%, 16 compounds), and unknown compounds (11.23\%, 10 
compounds). Queens possessed four specific alkenes (C27:1, C31:1, C33:1, and C35:1) which were never detected in other castes (Table 2, Figure 1).

\section{Caste- and colony-related CHC differences}

In all colonies analyzed, PCAs showed that workers, males, gynes, and queens displayed different CHC profiles, with queens always clearly differentiated on axis 2 (Figure 2, Table 3). A comparison of chemical signature among colonies also showed significant differences in PCAs, with queens more or less following their offspring but always well differentiated from other castes (Figure 3).

\section{Chemical distances in CHC profiles}

With regard to the chemical distances associated with CHC profiles (Figure 4), we found more difference between gynes and other castes within a given colony than among gynes from different colonies (Kruskal-Wallis, $\mathrm{P}<0.001$ ). Instead, the chemical signatures of males were not significantly different from those of other castes in the same colony or among different colonies ( $\mathrm{P}>0.05$; Figure 4). For workers, among-colony differences were larger than the chemical distances within colonies and among castes $(\mathrm{P}<0.001$; Figure 4$)$. For gynes, males, and workers, intra-caste chemical distances (i.e. among individuals in the same caste, whatever the colony) were always shorter than those among castes in the same colony or between colonies (all $\mathrm{P}<0.001$ ). Moreover, a comparison of intra-caste chemical distances revealed that these distances were largest among workers (workers vs males $\mathrm{P}<0.001$, workers vs gynes $\mathrm{P}<0.01)$, and greater in gynes than in males $(\mathrm{P}<0.05)$. Among colonies, the chemical distances among workers were larger than those among gynes and males $(\mathrm{P}<0.001$ in both cases), and were similar between gynes and males $(\mathrm{P}>0.05)$.

Figure 5 shows chemical distances between castes. The shortest distances were between comparisons of males and gynes and males and workers. Comparisons with queens always produced the highest distances.

\section{Quantitative analysis of $\mathrm{CHC}$ profiles}

Quantitatively, queens possessed more CHCs per gram of body weight than did the other individuals within a colony (Figure 6) (Kruskal-Wallis, $\mathrm{P}<0.001$ ). Gynes and males were similar to each other in terms of quantities of CHCs $(\mathrm{P}>0.05)$, but each had less than workers $(\mathrm{P}<0.001)$. The chromatograms of queens were characterized by the presence of two main alkanes, $n-\mathrm{C} 25$ and $n$-C27, in greater quantities than in other castes (Figure 1) [(n-C25: 7.7x 
more than in workers (Kruskal-Wallis $\mathrm{P}<0.001), 11.5 \mathrm{x}$ more than in gynes $(\mathrm{P}<0.001)$ and 10.9x more than in males $(\mathrm{P}<0.001)$; $n$-C27: 3.9x more than in workers $(\mathrm{P}<0.001), 10.1 \mathrm{x}$ more than in gynes $(\mathrm{P}<0.001)$, and $7.7 \mathrm{x}$ more than in males $(\mathrm{P}<0.001)$, plus the queenspecific alkenes described above in the paragraph "Analyses of $\mathrm{CHCs}$ ".

Figure 7 depicts differences between castes and genders in the chemical makeup of CHCs. With respect to the amounts present in gynes, males, and workers, queens possessed higher quantities of $n$-alkanes ( $\mathrm{P}<0.001$ for each comparison), monomethyl-alkanes $(\mathrm{P}<0.001)$, and alkenes $(\mathrm{P}<0.001)$, but the same quantities of dimethyl-alkanes $(\mathrm{P}>0.05)$. Workers possessed more $n$-alkanes than gynes and males $(\mathrm{P}<0.05$ with males; $\mathrm{P}<0.001$ with gynes), more monomethyl-alkanes than gynes $(\mathrm{P}<0.05)$ but a similar quantity as males ( $\mathrm{P}>0.05)$, and more dimethyl-alkanes than males and gynes ( $\mathrm{P}<0.001$ for each comparison). Gynes possessed less $n$-alkanes than males $(\mathrm{P}<0.001)$, but the same quantities of monomethyl-alkanes, dimethyl-alkanes, and alkenes ( $\mathrm{P}>0.05$ respectively).

\section{Discussion}

Our results demonstrated that, in spite of inbreeding (Darrouzet et al. 2015) linked to a genetic bottleneck (Arca et al. 2015), the chemical signature of the invasive hornet Vespa velutina in France is clearly heterogeneous. Each colony, caste, and gender possesses a specific CHC profile. This study thus suggests that $\mathrm{CHCs}$ could serve as a useful marker for discriminating yellow-legged hornet populations in France, the main invaded area of this species in Europe.

The chemical heterogeneity that we observed within the introduced hornet population in France was unexpected. Arca et al. (2015) demonstrated that native V. velutina populations near Shanghai (China) contained at least three different haplotypes. Little is currently known about the chemical signatures of yellow-legged hornets in their native area, but it is possible, indeed probable, that these populations have strongly heterogenenous $\mathrm{CHC}$ profiles. Instead, the introduced population in France has just one haplotype (Arca et al. 2015), but has notable chemical heterogeneity in $\mathrm{CHC}$ profiles. This result is surprising, because to our knowledge this type of hydrocarbon heterogeneity has not previously been detected in other introduced social insects. On the contrary, recent research has revealed homogeneity in $\mathrm{CHC}$ profiles in introduced ants (Linepithema humile: Brandt et al. 2009; Wasmannia auropunctata: Errard et al. 2005) and termites (Reticulitermes flavipes: Perdereau et al. 2010). These previous studies suggested that the reduced chemical variability of introduced populations may arise from the limited number of introduction events into a new environment. Specifically, the reduced variability of recognition cues, such as $\mathrm{CHCs}$, in these introduced populations of ants and 
termites has been attributed to a reduction of genetic diversity through a genetic bottleneck (Tsutsui et al. 2000) or to 'genetic cleansing', i.e. selection against the less-common recognition alleles (Giraud et al. 2002).

In the case of the invasive hornet $V$. velutina in France, which is an inbred population with a genetic bottleneck, the heterogeneity in $\mathrm{CHC}$ profiles may be affected by environmental and/or epigenetic parameters. For example, diet or laboratory rearing conditions are known to alter the chemical signature in termites (Shelton and Grace 1997; Polizzi and Forschler 1998; Florane et al. 2004). A change in ants' chemical signature could occurred over a short period of time, which is due to the ants walking over their prey (Liang and Silverman 2000). Because V. velutina is a generalist predator and can consume several different types of prey, it is possible that a particular diet specific to the area around a given colony could explain the $\mathrm{CHC}$ heterogeneity we observed. However, as hornets have a general diet, it is unlikely that any great overall differences could appear in such conditions. But this idea needs furthers studies to be verified. Seasonal variations could also alter $V$. velutina's chemical signatures, as has been observed in termite species (Bagnères et al. 1990); however, this cannot explain the differences reported here since we collected all hornet colonies in the same period of time. Another possible contributing factor could be the composition of the endosymbiont community in the digestive tract, as this has been reported to affect host chemical communication in termites (Matsuura 2001, 2003). Since these symbionts are probably obtained by new individuals thanks to trophallaxis with adult workers, it is possible that each $V$. velutina colony could possess a unique endosymbiont profile with specific effects on the CHC profiles of their host. Further studies are clearly necessary to analyze all these factors and their relative contributions to the hornet $\mathrm{CHC}$ profile.

These specific chemical signatures probably enable each individual to identify the colony and caste origins of conspecifics. In social insect colonies, labor is divided between a reproductive queen, reproductive individuals (gynes and males), and sterile workers (Wilson 1971). The distribution of tasks among individuals requires interactions among colony members which involve the recognition of caste membership and perhaps specific tasks inside the caste (more particularly in the worker caste) (Green and Gordon 2003). This process is generally based on chemical cues such as CHCs. For example, in bees and termites, castes can be distinguished by differences in CHC profiles (honeybees: Kather et al. 2011; termites: Bagnères et al. 1998, 2011; Darrouzet et al. 2014b; Haverty et al. 1996; Kaib et al. 2002; LeConte and Hefetz 2008; Nunes et al. 2009). Such differences were also observed across different age groups in Apis cerana workers and could serve as the basis for task allocation in 
that species (Rahman et al. 2015). Wagner et al. (1998) supposed that these caste-related differences in CHCs may be representative of the tasks performed by individuals, that is, the type and quantity of $\mathrm{CHCs}$ present could be linked to the tasks and specific environment of a given individual. For example, bee foragers are exposed more often than other workers to unfavorable environmental conditions, such as hot temperatures, high humidity, and harmful chemicals. Consequently, Rahman et al. (2015) suggested that the increased levels of $n$ alkanes observed in A. cerana foragers, compared with those of workers remaining inside the hive, could play an important role in regulating water impermeability, as had been previously proposed (Gibbs and Pomonis 1995). In the present study, we observed similar differences between $V$. velutina workers and reproductive individuals collected in nests (gynes and males). Such differences could be explained by the environment of individuals: most workers must contend with variable environmental conditions during their foraging activities while the reproductive individuals we analyzed (i.e. collected in their nests) stayed in the nest until their nuptial flight. However, eventually these gynes and males have to leave the nests and, like workers, will be confronted with variable environmental conditions. It is possible that their chemical signature adapts prior to leaving the nest by increasing the amount of $n$-alkanes present, though further studies are necessary to verify this hypothesis.

Interestingly, the $\mathrm{CHC}$ profiles of $V$. velutina queens possess two alkanes in great quantities ( $n$-C25 and $n$-C27) which seem to act as queen pheromones in other hymenopteran species, such as Lasius ants (Holman et al 2010, 2013), the bumble bee Bombus terrestris (Holman 2014), and the wasp Vespula vulgaris (Van Oystaeyen et al. 2014). These $n$ alkanes, which are present on queen cuticle, could induce sterility in workers. This reproductive inhibition of the sterile caste seems to occur via two distinct processes: first, by inhibiting the functioning of workers' ovaries, and second, by causing oocyte resorption (Van Oystaeyen et al. 2014). These saturated linear alkanes seem to be the most conserved class of queen pheromones in several hymenopterans (Van Oystaeyen et al. 2014), and could be used as a fertility signal in a common solitary ancestor of social hymenopteran species (Wilson et al. 2013). Our result seems consistent with this idea and adds a second Vespa species to the group of species, spanning major clades of social hymenoptera, which has yielded clues about the evolutionary history of queen and fertility signals. However, Amsalem et al (2015) tested three alkanes (n-C23, $n$-C25 and $n$-C27) in Bombus impatiens and found no evidence to support this theory that a conserved class of hydrocarbons serve as queen pheromones or queen signals. Moreover, we observed four unsaturated hydrocarbons (C27:1, C31:1, C33:1, and $\mathrm{C} 35: 1)$ specific to the chemical profile of $V$. velutina queens. As observed by Van 
Oystaeyen et al. (2014), some other compounds, including unsaturated hydrocarbons, can also be used as queen pheromones. In the Polistes, Apis, Bombus, and Lasius species in which they have been studied, these alkenes derive from saturated hydrocarbons, and can be obtained after biochemical modification during pheromone biosynthesis, from the up-regulation of specific desaturases (Blomquist \& Vogt 2003; Blomquist and Bagnères 2010; Qiu et al. 2012). Some alkene compounds are used as male attractants (sex pheromones), particularly in solitary species (Blomquist and Vogt 2003; Blomquist and Bagnères 2010). As hypothesized by Van Oystaeyen et al. (2014), different queen pheromone compounds have arisen as a result of the multiple independent origins of eusociality, particularly by evolving from a fertility signal directed to attract males in solitary ancestors. Further studies are necessary to test the function of these alkenes in $V$. velutina nigrithorax.

\section{Acknowledgments}

We gratefully acknowledge C. Poirier for his help in collecting colonies in the field and L. Higgins for her English revisions. This study was supported by funding from the Centre-Val de Loire region (French regional grant) for our "FRELON" and "FRELON 2" projects.

\section{Bibliography}

Amsalem E, Orlova M, Grozinger CM (2015). A conserved class of queen pheromones? Reevaluating the evidence in bumblebees (Bombus impatiens). Proc $\mathrm{R}$ Soc $\mathrm{B}$ 282(1817):20151800.

Arca M, Mougel F, Guillemaud T, Dupas S, Rome Q, Perrard A, Muller F, Fossoud A, Capdevielle-Dulac C, Torres-Leguizamon M, Chen X.X, Tan J.L, Jung C, Villemant C, Arnold G, Silvain J-F (2015). Reconstructing the invasion and the demographic history of the yellow-legged hornet, Vespa velutina, in Europe. Biol Invasions 17(8):2357-2371

Bagnères A-G, Clément J-L, Blum MS, Severson RF, Joulie C, Lange C (1990). Cuticular hydrocarbons and defensive compounds of Reticulitermes flavipes (Kollar) and $R$. santonensis (Feytaud): Polymorphism and chemotaxonomy. J Chem Ecol 16(12):32133244

Bagnères A-G, Killian A, Clément J-L, Lange C. (1991). Interspecific recognition among termites of the genus Reticulitermes: Evidence for a role for the cuticular hydrocarbons. $\mathbf{J}$ Chem Ecol 17(12):2397-2420

Bagnères A-G, Lorenzi MC, Dusticier G, Turillazzi S, Clément J-L (1996). Chemical usurpation of a nest by paper wasp parasites. Science, 272(5263):889 
Bagnères A-G, Rivière G, Clément J-L (1998). Artificial neural network modeling of caste odor discrimination based on cuticular hydrocarbons in termites. Chemoecology 8(4), 201-209

Bagnères A-G, Darrouzet É, Christidès J-P, Landré X (2011). Endogenous synchronization of the chemical signature of Reticulitermes (Isoptera, Rhinotermitidae) worker termites. Ann Soc Entomol France 47:202-208

Bagnères A-G, Wicker-Thomas C (2010). Chemical taxonomy with hydrocarbons. In Insect hydrocarbons: biology, biochemistry and chemical ecology. Cambridge University Press, Cambridge, pp 121-162

Blomquist GJ (2010) Biosynthesis of cuticular hydrocarbons. Insect hydrocarbons: biology, biochemistry, and chemical ecology. Cambridge University Press, Cambridge, pp 35-52

Blomquist GJ, Vogt RG (2003) Insect pheromone biochemistry and molecular biology: The biosynthesis and detection of pheromones and plant volatiles. Academic press, pp 745

Blomquist GJ, Bagnères A-G (2010). Insect hydrocarbons: biology, biochemistry, and chemical ecology. Cambridge University Press. pp 486

Bonavita-Cougourdan A, Rivière G, Provost E, Bagnères A-G, Roux M, Dusticier G, Clément J-L (1996) Selective adaptation of the cuticular hydrocarbon profiles of the slave-making ants Polyergus rufescens Latr. and their Formica rufibarbis Fab. and F. cunicularia Latr. slaves. Comp Biochem Physiol Part B: Biochem Mol Biol 113(2):313-329

Bonelli M, Lorenzi MC, Christidès J-P, Dupont S, Bagnères A-G (2015) Population diversity in cuticular hydrocarbons and mtDNA in a mountain social wasp. J Chem Ecol 41(1):2231

Brandt M, Van Wilgenburg E, Tsutsui ND (2009) Global-scale analyses of chemical ecology and population genetics in the invasive Argentine ant. Mol Ecol 18(5):997-1005

Darrouzet E, Gévar J (2014a) Le frelon asiatique à la conquête de l'Europe. La Santé de l'Abeille 259:49-59

Darrouzet E, Labédan M, Landré X, Perdereau E, Christidès J-P, Bagnères A-G (2014b) Endocrine control of cuticular hydrocarbon profiles during worker-to-soldier differentiation in the termite Reticulitermes flavipes. J Insect Physiol 61:25-33

Darrouzet E, Gévar J, Guignard Q, Aron S (2015) Production of early diploid males in European colonies of the invasive hornet Vespa velutina nigrithorax. Plos One 10(9):e0136680 
de Haro L, Labadie M, Chanseau P, Cabot C, Blanc-Brisset I, Penouil F, Toxicovigilance NCC (2010) Medical consequences of the Asian black hornet (Vespa velutina) invasion in Southwestern France. Toxicon 55(2):650-652

Dronnet S, Lohou C, Christidès J-P, Bagnères A-G (2006) Cuticular hydrocarbon composition reflects genetic relationship among colonies of the introduced termite Reticulitermes santonensis Feytaud. J Chem Ecol 32(5):1027

Errard C, Delabie J, Jourdan H, Hefetz A (2005) Intercontinental chemical variation in the invasive ant Wasmannia auropunctata (Roger) (Hymenoptera Formicidae): a key to the invasive success of a tramp species. Naturwissenschaften 92(7):319-323

Etges WJ, De Oliveira CC, Ritchie MG, Noor MA (2009) Genetics of incipient speciation in Drosophila mojavensis: II. Host plants and mating status influence cuticular hydrocarbon QTL expression and G× E interactions. Evolution 63(7):1712-1730

Fan Y, Schal C, Vargo EL, Bagnères A-G (2004) Characterization of termite lipophorin and its involvement in hydrocarbon transport. J Insect Physiol 50(7):609-620

Florane CB, Bland JM, Husseneder C, Raina AK (2004) Diet-mediated inter-colonial aggression in the Formosan subterranean termite Coptotermes formosanus. J Chem Ecol, 30(12):2559-2574

Gibbs A, Pomonis JG (1995) Physical properties of insect cuticular hydrocarbons: the effects of chain length, methyl-branching and unsaturation. Comp Biochem Physiol Part B: Biochem Mol Biol 112(2):243-249

Ginzel MD, Blomquist GJ (2016) Insect Hydrocarbons: Biochemistry and Chemical Ecology. In Extracellular Composite Matrices in Arthropods. Springer International Publishing. pp. $221-252$

Giraud T, Pedersen JS, Keller L (2002) Evolution of supercolonies: the Argentine ants of southern Europe. PNAS 99(9):6075-6079

Goldarazena A, Heredia IP, Romon P, Iturrondobeitia JC, Gonzalez M, Lopez S (2015) Spread of the yellow-legged hornet Vespa velutina nigrithorax du Buysson (Hymenoptera: Vespidae) across Northern Spain. EPPO Bulletin 45(1):133-138

Greene MJ, Gordon DM (2003) Social insects: cuticular hydrocarbons inform task decisions. Nature 423(6935):32-32

Haverty MI, Grace JK, Nelson LJ, Yamamoto RT (1996) Intercaste, intercolony, and temporal variation in cuticular hydrocarbons of Coptotermes formosanus shiraki (Isoptera: Rhinotermitidae). J Chem Ecol 22(10):1813-1834 
Haxaire J, Bouguet JP, Tamisier JP (2006) Vespa velutina Lepeletier, 1836, une redoutable nouveauté pour la faune de France (Hym., Vespidae). Bull Soc Entomol France 111(2):194-194

Holman L, Jørgensen CG, Nielsen J, d'Ettorre P (2010) Identification of an ant queen pheromone regulating worker sterility. Proceedings of the Royal Society of London B: Biol Sciences 277(1701):3793-3800

Holman L, Lanfear R, d'Ettorre P (2013) The evolution of queen pheromones in the ant genus Lasius. J Evol Biol 26(7):1549-1558

Holman L (2014) Bumblebee size polymorphism and worker response to queen pheromone. PeerJ 2:e604

Howard RW, Blomquist GJ (2005) Ecological, behavioral, and biochemical aspects of insect hydrocarbons. Annu Rev Entomol 50:371-393

Kaib M, Eisermann B, Schoeters E, Billen J, Franke S, Francke W (2000) Task-related variation of postpharyngeal and cuticular hydrocarbon compositions in the ant Myrmicaria eumenoides. J Comp Physiol A 186(10):939-948

Kaib M, Franke S, Francke W, Brandl R (2002) Cuticular hydrocarbons in a termite: Phenotypes and a neighbour-stranger effect. Physiol Entomol 27(3):189-198

Kather R, Drijfhout FP, Martin SJ (2011) Task group differences in cuticular lipids in the honey bee Apis mellifera. J Chem Ecol 37(2):205-212

Lebreton S, Labarussias M, Chevrier C, Darrouzet E (2009) Discrimination of the age of conspecific eggs by an ovipositing ectoparasitic wasp. Entomol Exp Appl 130(1):28-34

Lebreton S, Chevrier C, Darrouzet E (2010) Sex allocation strategies in response to conspecifics' offspring sex ratio in solitary parasitoids. Behav Ecol 21(1):107-112

LeConte Y, Hefetz A (2008) Primer pheromones in social hymenoptera. Annu Rev Entomol 53:523-542

LeConte Y, Huang ZY, Roux M, Zeng ZJ, Christidès J-P, Bagnères A-G (2015) Varroa destructor changes cuticular hydrocarbons to mimic its new host, even when the new host is of a different species. Biol Letters 11(6):20150233

Lengyel F, Westerlund SA, Kaib M (2007) Juvenile hormone III influences task-specific cuticular hydrocarbon profile changes in the ant Myrmicaria eumenoides. J Chem Ecol 33(1):167-181

Liang D, Silverman J (2000) "You are what you eat": diet modifies cuticular hydrocarbons and nestmate recognition in the Argentine ant, Linepithema humile. Naturwissenschaften 87(9):412-416 
Matsuura K (2001) Nestmate recognition mediated by intestinal bacteria in a termite, Reticulitermes speratus. Oikos 92(1):20-26

Matsuura K (2003) Symbionts affecting termite behavior. CRC Press Inc., Boca Raton. pp. $131-143$

Monceau K, Maher N, Bonnard O, Thiéry D (2013) Predation pressure dynamics study of the recently introduced honeybee killer Vespa velutina: learning from the enemy. Apidologie 44(2):209-221

Nowbahari E, Lenoir A, Clément J-L, Lange C, Bagnères A-G, Joulie C (1990) Individual, geographical and experimental variation of cuticular hydrocarbons of the ant Cataglyphis cursor (Hymenoptera: Formicidae): their use in nest and subspecies recognition. Biochem Syst Ecol 18(1):63-73

Nunes TM, Turatti ICC, Mateus S, Nascimento FS, Lopes NP, Zucchi R (2009) Cuticular hydrocarbons in the stingless bee Schwarziana quadripunctata (Hymenoptera, Apidae, Meliponini): differences between colonies, castes and age. Genet Mol Res 8:589-595

Perdereau E, Dedeine F, Christidès J-P, Bagnères A-G (2010) Variations in worker cuticular hydrocarbons and soldier isoprenoid defensive secretions within and among introduced and native populations of the subterranean termite, Reticulitermes flavipes. J Chem Ecol 36(11):1189-1198

Polizzi JM, Forschler BT (1998) Intra-and interspecific agonism in Reticulitermes flavipes (Kollar) and R. virginicus (Banks) and effects of arena and group size in laboratory assays. Insectes sociaux 45(1):43-49

Qiu Y, Tittiger C, Wicker-Thomas C, Le Goff G, Young S, Wajnberg E, Fricaux T, Taquet N, Blomquist GJ, Feyereisen R (2012) An insect-specific P450 oxidative decarbonylase for cuticular hydrocarbon biosynthesis. PNAS 109(37):14858-14863

Rahman S, Hajong SR, Gévar J, Lenoir A, Darrouzet E (2016) Cuticular hydrocarbon compounds in worker castes and their role in nestmate recognition in Apis cerana indica. J Chem Ecol 42(5):444-451

Robinet C, Suppo C, Darrouzet E (2017) Rapid spread of the invasive yellow-legged hornet in France: the role of human-mediated dispersal and the effects of control measures. J App Ecol 54:205-215

Rome Q, Muller FJ, Touret-Alby A, Darrouzet E, Perrard A, Villemant C (2015) Caste differentiation and seasonal changes in Vespa velutina (Hym.: Vespidae) colonies in its introduced range. J App Entomol 139(10):771-782 
Shelton TG, Grace JK (1997) Impact of low temperature conditioning on-intercolonial agonism in Coptotermes formosanus. Sociobiology 30(2)

Smith RK, Taylor Jr OR (1990) Unsaturated extracted hydrocarbon caste differences between European queen and worker honey bees, Apis mellifera L. (Hymenoptera: Apidae). J Kansas Entomol Soc 369-374

Takeuchi T, Takahashi R, Kiyoshi T, Nakamura M, Minoshima YN, Takahashi J (2017). The origin and genetic diversity of the yellow-legged hornet, Vespa velutina introduced in Japan. Insectes Sociaux, 1-8

Thomas ML, Simmons LW (2008) Cuticular hydrocarbons are heritable in the cricket Teleogryllus oceanicus. J Evol Biol 21(3):801-806

Tsutsui ND, Suarez AV, Holway DA, Case TJ (2000) Reduced genetic variation and the success of an invasive species. PNAS 97(11):5948-5953

Vander Meer RK, Morel L (1998) Nestmate recognition in ants, in: VanderMeer R.K., Breed M.D., Espelie K.E., Winston M.L. (Eds.). Pheromone communication in social insects. Ants, wasps, bees and termites. Westview Press, Boulder, USA, pp. 79-103

Van Oystaeyen A, Oliveira RC, Holman L, van Zweden JS, Romero C, Oi CA, Millar JG (2014) Conserved class of queen pheromones stops social insect workers from reproducing. Science 343(6168):287-290

Van Zweden JS, d'Ettorre P (2010) Nestmate recognition in social insects and the role of hydrocarbons. Insect hydrocarbons: biology, biochemistry and chemical ecology 11:222243

Vauchot B, Provost E, Bagnères A-G, Clément J-L (1996) Regulation of the chemical signatures of two termite species, Reticulitermes santonensis and Reticulitermes lucifugus grassei, living in mixed experimental colonies. J Insect Physiol 42(4):309-321

Wagner D, Brown MJF, Broun P, Cuevas W, Moses LE, Chao DL, Gordon DM (1998) Taskrelated differences in the cuticular hydrocarbon composition of harvester ants, Pogonomyrmex barbatus. J Chem Ecol 24:2021-2037

Wilson EO (1971) Social insects. Science 172(3981):406-406

Wilson JS, von Dohlen CD, Forister ML, Pitts JP (2013) Family-level divergences in the stinging wasps (Hymenoptera: Aculeata), with correlations to angiosperm diversification. Evol Biol 40(1):101-107 
481

482

\section{Legends}

Figure 1: Typical chromatograms of queens, gynes, males, and workers.

Figure 2: Plot of the first two axes of the Principal Components Analysis (PCA) of the proportion of $\mathrm{CHCs}$ in the different castes within $V$. velutina colonies.

Figure 3: Plot of the first two axes of the Principal Components Analysis (PCA) of the proportion of $\mathrm{CHCs}$ in the different castes (queens, males, workers, and gynes) among different colonies.

Figure 4: Calculation of chemical distances based on comparisons of $\mathrm{CHC}$ profiles of workers, gynes, and males. "Intra-caste" represents the distance between individuals in the same caste and in the same colony, "inter-caste" is between the analyzed caste and the others castes in the same colony, and "inter-colony" is for the same caste but among colonies.

Figure 5: Comparisons of inter-caste chemical distances. The different letters for each distance were obtained with $\mathrm{P}<0.01$ (Kruskal-Wallis test). $\mathrm{G}=$ gynes, $\mathrm{m}=$ males, $\mathrm{q}=$ queens, $\mathrm{w}=$ workers.

Figure 6: Quantitative analysis of total CHC profiles (gram of CHCs per gram of insect) in workers, queens, gynes, and males.

Figure 7: Quantitative analysis of alkanes, alkenes, monomethyl-alkanes, and dimethylalkanes in CHC profiles (gram of CHCs per gram of insect) from workers, queens, gynes, and males. 
Table 1 Origins and dates of sample collection and sample sizes.

\begin{tabular}{|c|c|c|c|c|c|c|}
\hline \multirow[b]{2}{*}{ Colonies' origines } & \multirow[b]{2}{*}{ Lambert 93 coordinates } & \multirow{2}{*}{$\begin{array}{c}\text { Dates of } \\
\text { sample } \\
\text { collections }\end{array}$} & \multicolumn{4}{|c|}{ Number of } \\
\hline & & & Males & Workers & Gynes & Queens \\
\hline Chinon & X : 491725 Y : 6677696 & $07 / 10 / 2011$ & 10 & 0 & 0 & 0 \\
\hline Sepmes & $X: 522947$ Y : 6665711 & $17 / 10 / 2011$ & 10 & 10 & 10 & 0 \\
\hline Barrou & $X: 530076$ Y : 6643026 & $24 / 10 / 2011$ & 8 & 4 & 10 & 0 \\
\hline Ligueil $(A)$ & $X: 534307$ Y : 6662641 & $25 / 10 / 2011$ & 5 & 10 & 10 & 1 \\
\hline Azay sur Indre & $X: 544621$ Y : 6680754 & $21 / 11 / 2011$ & 10 & 0 & 0 & 0 \\
\hline Ligueil $(B)$ & $X: 534307$ Y : 6662641 & $26 / 11 / 2011$ & 10 & 10 & 4 & 0 \\
\hline Civray de touraine & $X: 552648$ Y : 6694251 & $01 / 12 / 2011$ & 10 & 10 & 10 & 0 \\
\hline Reignac sur Indre & X : 542394 Y : 6683401 & $06 / 12 / 2011$ & 0 & 10 & 0 & 0 \\
\hline Lussault sur Loire & $X: 542876$ Y : 6701668 & $16 / 10 / 2012$ & 10 & 10 & 0 & 0 \\
\hline Montlouis sur Loire & $X: 536567$ Y : 6700904 & $22 / 10 / 2012$ & 10 & 10 & 10 & 1 \\
\hline Lerné & $X: 482765$ Y : 6674503 & $23 / 10 / 2012$ & 10 & 10 & 10 & 0 \\
\hline Artannes & $X: 518507$ Y : 6688647 & 08/11/2012 & 10 & 10 & 10 & 0 \\
\hline Athée sur Cher & $X: 542527$ Y : 6693243 & $09 / 11 / 2012$ & 10 & 10 & 0 & 0 \\
\hline St Avertin & $X: 528458$ Y : 6698865 & $27 / 08 / 2013$ & 10 & 10 & 0 & 1 \\
\hline Tours & $X: 525709$ Y : 6701535 & $16 / 09 / 2013$ & 10 & 10 & 0 & 1 \\
\hline Ligueil $(C)$ & $X: 534307$ Y : 6662641 & $11 / 10 / 2013$ & 10 & 10 & 0 & 1 \\
\hline
\end{tabular}

499
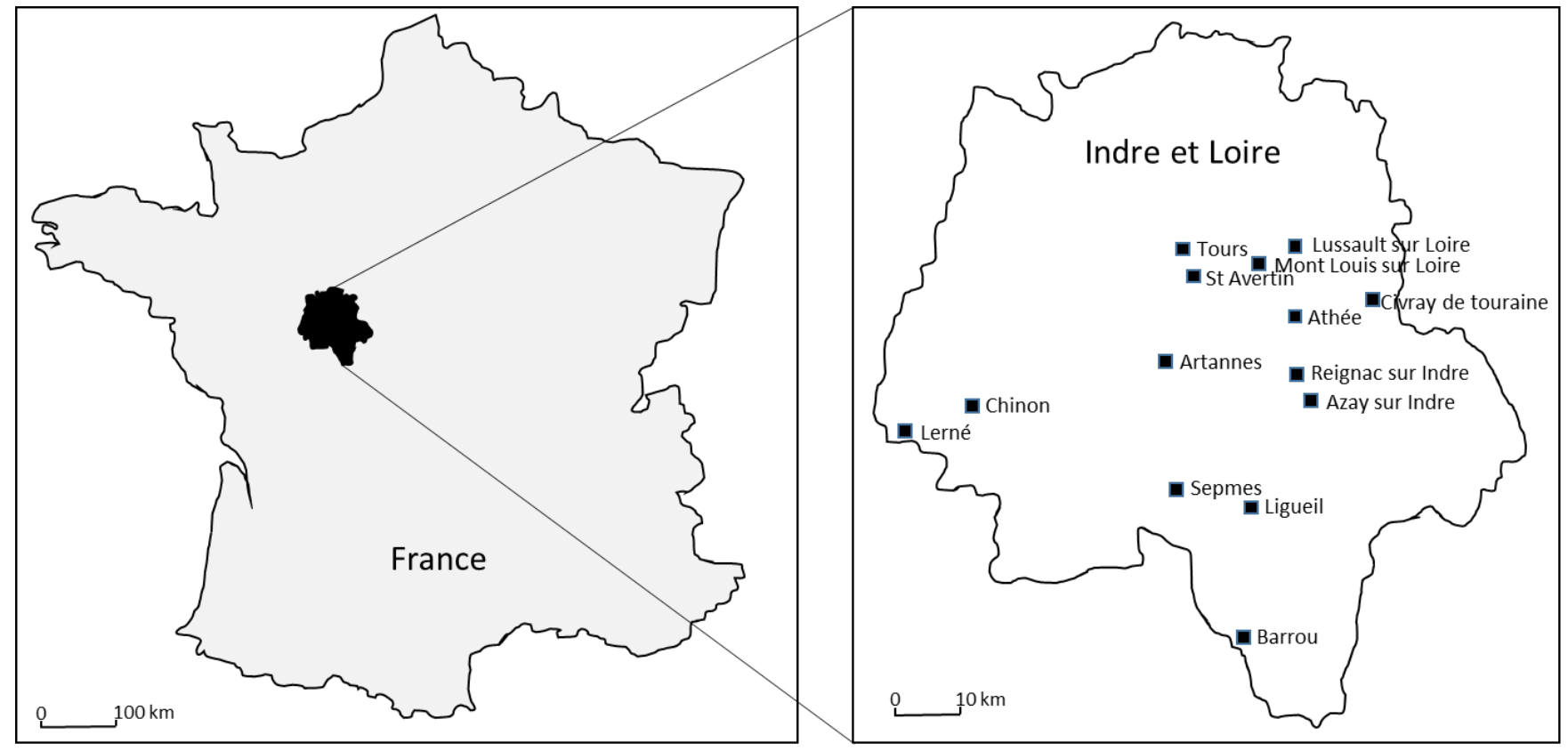
502 Table 1S Origins and dates of sample collection for insect pools to identify $\mathrm{CHC}$ chemical 503 signatures (one individual was isolated from each colony).

504

\begin{tabular}{|c|c|c|}
\hline pool of & Colonies from & $\begin{array}{c}\text { Dates of sample } \\
\text { collections }\end{array}$ \\
\hline \multirow[t]{9}{*}{ Males } & Bourgueil & 17/10/2011 \\
\hline & Sepmes & $17 / 10 / 2011$ \\
\hline & Azay sur Indre & $21 / 11 / 2011$ \\
\hline & Civray de touraine & $01 / 12 / 2011$ \\
\hline & Lussault & $16 / 10 / 2012$ \\
\hline & Montlouis sur Loire & $22 / 10 / 2012$ \\
\hline & Lerné & $23 / 10 / 2012$ \\
\hline & Athée & $09 / 11 / 2012$ \\
\hline & Tours & $16 / 092013$ \\
\hline \multirow[t]{9}{*}{ Workers } & Sepmes & $17 / 10 / 2011$ \\
\hline & Chinon & $28 / 10 / 2011$ \\
\hline & Azay sur Indre & $21 / 11 / 2011$ \\
\hline & Ligueil & $26 / 11 / 2011$ \\
\hline & Civray de touraine & $01 / 12 / 2011$ \\
\hline & Reignac sur Indre & $06 / 12 / 2011$ \\
\hline & Montlouis sur Loire & $22 / 10 / 2012$ \\
\hline & Lerné & $23 / 10 / 2012$ \\
\hline & Artannes & $08 / 11 / 2012$ \\
\hline \multirow[t]{9}{*}{ Gynes } & Sepmes & $17 / 10 / 2011$ \\
\hline & Barrou & $24 / 10 / 2011$ \\
\hline & Ligueil $(b)$ & $25 / 10 / 2011$ \\
\hline & $\operatorname{Ligueil}(a)$ & $26 / 11 / 2011$ \\
\hline & Civray de touraine & $01 / 12 / 2011$ \\
\hline & Montlouis sur Loire & $22 / 10 / 2012$ \\
\hline & Lerné & $23 / 10 / 2012$ \\
\hline & Artannes & 08/11/2012 \\
\hline & Orléans & $12 / 12 / 2012$ \\
\hline \multirow[t]{5}{*}{ Queens } & Ligueil $(b)$ & $25 / 10 / 2011$ \\
\hline & Montlouis sur Loire & $22 / 10 / 2012$ \\
\hline & St Avertin & $27 / 08 / 2013$ \\
\hline & Tours & $16 / 09 / 2013$ \\
\hline & Liguei $(c)$ & $11 / 10 / 2013$ \\
\hline
\end{tabular}


506 Table 2 Identification and relative proportion of the cuticular hydrocarbon compounds 507 (CHCs) in the chemical signature of each caste of Vespa velutina. Compounds are the same 508 between males and females (workers and gynes). Peaks pQ1 to pQ4 are queen-specifics.

\begin{tabular}{|c|c|c|c|c|c|c|c|c|c|c|c|}
\hline \multirow[b]{2}{*}{ Peaks } & \multirow[b]{2}{*}{$\mathrm{RT}(\min )$} & \multirow[b]{2}{*}{ ECL } & \multirow[b]{2}{*}{ Identification } & \multicolumn{2}{|c|}{ Workers } & \multicolumn{2}{|c|}{ Males } & \multicolumn{2}{|c|}{ Gynes } & \multicolumn{2}{|c|}{ Queens } \\
\hline & & & & $\%$ & $\pm \mathrm{SE}$ & $\%$ & $\pm \mathrm{SE}$ & $\%$ & $\pm \mathrm{SE}$ & $\%$ & $\pm \mathrm{SE}$ \\
\hline $\mathrm{C} 20$ & 23,12 & 20,00 & n-eicosane & & & & & & & & \\
\hline p1 & 24,66 & 21,00 & $n-\mathrm{C} 21$ & 0,23 & 0,31 & 0,48 & 0,63 & 0,56 & 1,22 & 0,20 & 0,06 \\
\hline $\mathrm{p} 2$ & 25,27 & 21,38 & 11-MeC21 & 0,59 & 1,17 & 0,50 & 0,46 & 0,26 & 0,35 & 0,19 & 0,12 \\
\hline p3 & 26,26 & 22,00 & $n-\mathrm{C} 22$ & 0,03 & 0,05 & 0,10 & 0,17 & 0,08 & 0,13 & 0,04 & 0,01 \\
\hline $\mathrm{p} 4$ & 27,47 & 22,75 & $\mathrm{C} 23: 1$ & 0,09 & 0,13 & 0,14 & 0,16 & 0,24 & 0,24 & 0,03 & 0,02 \\
\hline p5 & 27,58 & 22,81 & $\mathrm{C} 23: 1$ & 0,03 & 0,09 & 0,03 & 0,05 & 0,03 & 0,05 & 0,01 & 0,00 \\
\hline p6 & 27,89 & 23,00 & $n-\mathrm{C} 23$ & 2,03 & 2,41 & 4,14 & 3,83 & 5,01 & 6,65 & 2,99 & 0,58 \\
\hline p7 & 28,45 & 23,36 & 11-MeC23 & 0,11 & 0,14 & 0,21 & 0,20 & 0,29 & 0,20 & 0,05 & 0,02 \\
\hline p8 & 28,55 & 23,42 & 7-MeC23 & 0,01 & 0,02 & 0,02 & 0,05 & 0,03 & 0,04 & 0,01 & 0,00 \\
\hline $\mathrm{p} 9$ & 28,68 & 23,51 & 5-MeC23 & 0,00 & 0,00 & 0,00 & 0,01 & 0,01 & 0,02 & 0,01 & 0,00 \\
\hline p10 & 29,03 & 23,73 & 3-MeC23 & 0,11 & 0,07 & 0,16 & 0,11 & 0,24 & 0,11 & 0,09 & 0,03 \\
\hline $\mathrm{p} 11$ & 29,46 & 24,00 & $n-\mathrm{C} 24$ & 0,36 & 0,18 & 0,59 & 0,51 & 0,48 & 0,21 & 0,83 & 0,13 \\
\hline $\mathrm{p} 12$ & 30,02 & 24,34 & 12-MeC24 & 0,08 & 0,06 & 0,10 & 0,06 & 0,13 & 0,03 & 0,02 & 0,01 \\
\hline p13 & 30,68 & 24,75 & $\mathrm{C} 25: 1$ & 1,21 & 0,63 & 1,27 & 0,74 & 2,10 & 1,46 & 1,53 & 0,73 \\
\hline p14 & 30,78 & 24,81 & $\mathrm{C} 25: 1$ & 0,17 & 0,10 & 0,23 & 0,10 & 0,31 & 0,09 & 0,09 & 0,03 \\
\hline p15 & 31,08 & 25,00 & $n-\mathrm{C} 25$ & 14,93 & 4,56 & 17,94 & 5,38 & 14,96 & 4,98 & 39,84 & 4,60 \\
\hline p16 & 31,59 & 25,34 & 13-+11-MeC25 & 2,09 & 1,45 & 2,77 & 1,54 & 5,79 & 1,06 & 0,65 & 0,21 \\
\hline p17 & 31,70 & 25,41 & 7-MeC25 & 0,18 & 0,13 & 0,25 & 0,12 & 0,49 & 0,11 & 0,05 & 0,02 \\
\hline p18 & 31,83 & 25,50 & 5-MeC25 & 0,40 & 0,14 & 0,39 & 0,16 & 0,54 & 0,40 & 0,39 & 0,09 \\
\hline p19 & 32,05 & 25,65 & $\mathrm{C} 26: 1$ & 0,09 & 0,06 & 0,06 & 0,07 & 0,17 & 0,05 & 0,01 & 0,01 \\
\hline p20 & 32,19 & 25,73 & 3-MeC25 & 4,34 & 1,28 & 4,67 & 1,42 & 4,15 & 1,11 & 4,12 & 0,85 \\
\hline $\mathrm{p} 21$ & 32,33 & 25,83 & 5,11-+5,9-diMeC25 & 0,21 & 0,09 & 0,14 & 0,05 & 0,25 & 0,06 & 0,08 & 0,02 \\
\hline $\mathrm{p} 22$ & 32,58 & 26,00 & $n-\mathrm{C} 26$ & 1,32 & 0,54 & 1,38 & 0,95 & 1,00 & 0,41 & 2,25 & 0,34 \\
\hline $\mathrm{p} 23$ & 32,68 & 26,07 & diMe or triMeC25 & 0,15 & 0,07 & 0,08 & 0,04 & 0,19 & 0,11 & 0,14 & 0,05 \\
\hline $\mathrm{p} 24$ & 33,09 & 26,33 & 12-+10-MeC26 & 0,56 & 0,21 & 0,56 & 0,16 & 0,97 & 0,22 & 0,12 & 0,03 \\
\hline $\mathrm{p} 25$ & 33,21 & 26,41 & $?$ & 0,00 & 0,00 & 0,01 & 0,02 & 0,03 & 0,04 & 0,02 & 0,00 \\
\hline p26 & 33,27 & 26,45 & $?$ & 0,05 & 0,03 & 0,03 & 0,03 & 0,03 & 0,02 & 0,02 & 0,00 \\
\hline p27 & 33,35 & 26,50 & $?$ & 0,02 & 0,04 & 0,01 & 0,02 & 0,03 & 0,03 & 0,03 & 0,01 \\
\hline $\mathrm{p} 28$ & 33,47 & 26,58 & 4-MeC26 & 0,37 & 0,16 & 0,25 & 0,09 & 0,17 & 0,05 & 0,29 & 0,04 \\
\hline pQ1 & 33,64 & 26,69 & $\mathrm{C} 27: 1$ & 0,00 & 0,00 & 0,00 & 0,00 & 0,00 & 0,00 & 1,59 & 0,86 \\
\hline p29 & 33,78 & 26,78 & $\mathrm{C} 27: 1$ & 7,98 & 5,83 & 5,88 & 1,66 & 6,58 & 2,23 & 3,39 & 1,31 \\
\hline p30 & 33,87 & 26,84 & $\mathrm{C} 27: 1$ & 3,57 & 5,99 & 0,78 & 0,22 & 0,86 & 0,15 & 0,19 & 0,13 \\
\hline p31 & 34,12 & 27,00 & $n-\mathrm{C} 27$ & 10,73 & 6,18 & 12,23 & 3,76 & 8,21 & 2,06 & 19,95 & 2,62 \\
\hline p32 & 34,61 & 27,34 & 13-+11-+9-MeC27 & 6,99 & 2,58 & 8,79 & 2,67 & 13,37 & 3,34 & 1,19 & 0,60 \\
\hline p33 & 34,72 & 27,42 & 7-MeC27 & 0,96 & 0,38 & 1,04 & 0,38 & 1,79 & 0,59 & 0,39 & 0,13 \\
\hline p34 & 34,85 & 27,51 & 5-MeC27 & 0,80 & 0,43 & 0,63 & 0,39 & 0,65 & 0,21 & 0,69 & 0,12 \\
\hline p35 & 35,00 & 27,62 & 11,15-diMeC27 & 3,40 & 1,26 & 2,42 & 0,75 & 3,06 & 1,07 & 0,33 & 0,23 \\
\hline p36 & 35,06 & 27,66 & 9,15-diMeC27 & 0,33 & 0,60 & 0,04 & 0,18 & 0,37 & 0,53 & 0,00 & 0,00 \\
\hline
\end{tabular}




\begin{tabular}{|c|c|c|c|c|c|c|c|c|c|c|c|}
\hline p37 & 35,20 & 27,75 & 3-MeC27 & 7,47 & 2,56 & 7,22 & 3,24 & 4,68 & 1,46 & 5,66 & 0,83 \\
\hline p38 & 35,31 & 27,83 & 5,15-diMeC27 & 1,40 & 2,43 & 0,54 & 0,28 & 0,72 & 0,29 & 0,19 & 0,05 \\
\hline p39 & 35,38 & 27,88 & $?$ & 0,39 & 0,64 & 0,41 & 0,39 & 0,10 & 0,11 & 0,07 & 0,04 \\
\hline $\mathrm{p} 40$ & 35,45 & 27,92 & $?$ & 0,06 & 0,35 & 0,00 & 0,01 & 0,05 & 0,04 & 0,00 & 0,00 \\
\hline $\mathrm{p} 41$ & 35,56 & 28,00 & $n-\mathrm{C} 28$ & 0,89 & 0,69 & 0,74 & 1,05 & 0,40 & 0,33 & 0,33 & 0,03 \\
\hline $\mathrm{p} 42$ & 35,64 & 28,06 & diMe or triMeC27 & 0,89 & 0,76 & 0,72 & 0,49 & 0,55 & 0,28 & 0,50 & 0,12 \\
\hline $\mathrm{p} 43$ & 36,02 & 28,32 & 12-MeC28 & 0,50 & 0,47 & 0,44 & 0,23 & 0,67 & 0,21 & 0,15 & 0,06 \\
\hline p44 & 36,28 & 28,50 & 8-MeC28 & 0,54 & 1,32 & 0,18 & 0,76 & 0,02 & 0,02 & 0,05 & 0,02 \\
\hline $\mathrm{p} 45$ & 36,42 & 28,60 & 4-MeC28 & 0,67 & 1,01 & 0,83 & 1,89 & 0,28 & 0,14 & 0,15 & 0,04 \\
\hline $\mathrm{p} 46$ & 36,55 & 28,70 & $\mathrm{C} 29: 2$ & 0,58 & 1,00 & 0,60 & 1,47 & 0,10 & 0,05 & 1,42 & 0,62 \\
\hline $\mathrm{p} 47$ & 36,70 & 28,80 & C29:1 & 3,94 & 2,68 & 2,81 & 1,17 & 2,29 & 0,81 & 0,62 & 0,20 \\
\hline $\mathrm{p} 48$ & 36,82 & 28,88 & $\mathrm{C} 29: 1$ & 2,45 & 1,72 & 0,98 & 0,30 & 0,71 & 0,17 & 0,28 & 0,15 \\
\hline $\mathrm{p} 49$ & 36,99 & 29,00 & $n-\mathrm{C} 29$ & 1,49 & 0,76 & 1,61 & 1,13 & 0,84 & 0,34 & 1,32 & 0,20 \\
\hline p50 & 37,29 & 29,27 & $?$ & 0,57 & 0,63 & 0,67 & 0,40 & 0,26 & 0,13 & 0,21 & 0,08 \\
\hline p51 & 37,44 & 29,40 & $13-+11-+9-\mathrm{MeC} 29$ & 1,52 & 0,63 & 1,97 & 0,64 & 3,00 & 0,87 & 0,44 & 0,17 \\
\hline p52 & 37,57 & 29,51 & 7-MeC29 & 0,07 & 0,13 & 0,09 & 0,06 & 0,20 & 0,11 & 0,05 & 0,01 \\
\hline p53 & 37,82 & 29,73 & 11,15-+11,17-diMeC29 & 2,34 & 0,62 & 1,85 & 0,66 & 2,12 & 0,79 & 0,26 & 0,15 \\
\hline p54 & 37,90 & 29,81 & 3-МeC29 & 0,37 & 0,30 & 0,39 & 0,27 & 0,67 & 0,48 & 0,14 & 0,05 \\
\hline p55 & 38,02 & 29,92 & 5,17-diMeC29 & 0,56 & 0,31 & 0,44 & 0,20 & 0,24 & 0,15 & 0,48 & 0,07 \\
\hline p56 & 38,12 & 30,00 & $n-\mathrm{C} 30$ & 0,46 & 0,22 & 0,26 & 0,15 & 0,27 & 0,11 & 0,18 & 0,05 \\
\hline p57 & 38,81 & 30,43 & 4-MeC30 & 1,30 & 1,30 & 0,94 & 0,90 & 0,78 & 0,59 & 0,20 & 0,09 \\
\hline pQ2 & 39,31 & 30,74 & $\mathrm{C} 31: 1$ & 0,00 & 0,00 & 0,00 & 0,00 & 0,00 & 0,00 & 0,94 & 0,28 \\
\hline p58 & 39,47 & 30,84 & C31:1 & 0,49 & 0,28 & 0,40 & 0,15 & 0,28 & 0,10 & 0,12 & 0,03 \\
\hline p59 & 39,61 & 30,93 & $?$ & 0,20 & 0,08 & 0,15 & 0,08 & 0,09 & 0,04 & 0,05 & 0,01 \\
\hline p60 & 39,73 & 31,00 & $n-\mathrm{C} 31$ & 0,34 & 0,29 & 0,57 & 0,64 & 0,32 & 0,27 & 0,29 & 0,05 \\
\hline p61 & 40,14 & 31,31 & 15-+13-+11-MeC31 & 0,69 & 0,39 & 1,06 & 0,35 & 1,39 & 0,53 & 0,31 & 0,07 \\
\hline p62 & 40,36 & 31,48 & $?$ & 0,06 & 0,18 & 0,21 & 0,41 & 0,04 & 0,09 & 0,03 & 0,01 \\
\hline p63 & 40,49 & 31,58 & 11,15-diMeC31 & 1,51 & 0,62 & 1,53 & 0,65 & 1,86 & 0,80 & 0,24 & 0,13 \\
\hline pQ3 & 41,94 & 32,69 & $\mathrm{C} 33: 1$ & 0,00 & 0,00 & 0,00 & 0,00 & 0,00 & 0,00 & 1,65 & 0,80 \\
\hline p64 & 42,07 & 32,79 & $\mathrm{C} 33: 1$ & 0,17 & 0,17 & 0,15 & 0,11 & 0,12 & 0,13 & 0,07 & 0,02 \\
\hline p65 & 42,34 & 33,00 & $n-\mathrm{C} 33$ & 0,16 & 0,26 & 0,30 & 0,42 & 0,15 & 0,13 & 0,11 & 0,02 \\
\hline p66 & 42,75 & 33,26 & 15-+13-+11-МeC33 & 0,40 & 0,23 & 0,66 & 0,27 & 0,78 & 0,40 & 0,18 & 0,05 \\
\hline p67 & 43,15 & 33,53 & 11,19-+11,17-diMeC33 & 1,04 & 0,47 & 0,99 & 0,49 & 1,01 & 0,49 & 0,23 & 0,09 \\
\hline p68 & 44,46 & 34,38 & $?$ & 0,36 & 0,52 & 0,41 & 0,44 & 0,22 & 0,30 & 0,42 & 0,23 \\
\hline pQ4 & 44,73 & 34,56 & $\mathrm{C} 35: 1$ & 0,00 & 0,00 & 0,00 & 0,00 & 0,00 & 0,00 & 0,41 & 0,27 \\
\hline p69 & 45,80 & 35,26 & 11-MeC35 & 0,24 & 0,14 & 0,38 & 0,21 & 0,37 & 0,23 & 0,12 & 0,04 \\
\hline p70 & 46,27 & 35,57 & 13,19-+11,17-diMeC35 & 1,19 & 0,63 & 1,10 & 0,65 & 0,95 & 0,54 & 0,25 & 0,09 \\
\hline p71 & 46,49 & 35,71 & $?$ & 0,16 & 0,12 & 0,09 & 0,08 & 0,06 & 0,05 & 0,06 & 0,03 \\
\hline
\end{tabular}


512 Table 3 Caste comparisons of each cuticular hydrocarbon compound (CHCs) in the chemical

513 signature (Kruskal-Wallis chi-squared test).

Caste comparisons

\begin{tabular}{|c|c|c|c|c|c|c|c|}
\hline \multirow[b]{2}{*}{ Peaks } & \multirow[b]{2}{*}{ global comparison } & \\
\hline & & Male-Workers & Male-Queen & Males-Gynes & Workers-Queens & Workers-Gynes & Gynes-Queens \\
\hline $\mathrm{p} 1$ & $x^{2}=23.7183, d f=3, p=2.86 e-05$ & $p=0.001$ & N.S & N.S & N.S & $p=0.01$ & N.S \\
\hline p2 & $X^{2}=12.9491, d f=3, p=0.004748$ & N.S & N.S & $p=0.01$ & N.S & N.S & N.S \\
\hline p3 & $X^{2}=21.2598, d f=3, p=9.297 e-05$ & $p=0.01$ & N.S & N.S & N.S & $p=0.001$ & N.S \\
\hline $\mathrm{p} 4$ & $X^{2}=30.3086, d f=3, p=1.188 e-06$ & N.S & N.S & $p=0.01$ & N.S & $p=0.001$ & $p=0.001$ \\
\hline p5 & $X^{2}=14.4091, d f=3, p=0.002398$ & N.S & N.S & N.S & N.S & $p=0.05$ & N.S \\
\hline p6 & $x^{2}=41.2662, d f=3, p=5.742 e-09$ & $p=0.001$ & N.S & N.S & $p=0.01$ & $p=0.001$ & N.S \\
\hline p7 & $X^{2}=68.7282, d f=3, p=7.99 e-15$ & $p=0.001$ & $p=0.01$ & $p=0.01$ & N.S & $p=0.001$ & $p=0.001$ \\
\hline p8 & $X^{2}=47.6831, d f=3, p=2.487 e-10$ & $p=0.05$ & N.S & $p=0.05$ & $p=0.01$ & $p=0.001$ & N.S \\
\hline p9 & $X^{2}=99.9361, d f=3, p<2.2 e-16$ & N.S & $p=0.001$ & N.S & $p=0.001$ & N.S & $p=0.001$ \\
\hline $\mathrm{p} 10$ & $X^{2}=61.3123, d f=3, p=3.082 e-13$ & $p=0.01$ & N.S & $p=0.001$ & N.S & $p=0.001$ & $p=0.001$ \\
\hline $\mathrm{p} 11$ & $X^{2}=55.6694, d f=3, p=4.942 e-12$ & $p=0.001$ & $p=0.001$ & N.S & $p=0.001$ & $p=0.01$ & $p=0.001$ \\
\hline p12 & $X^{2}=67.5535, d f=3, p=1.426 e-14$ & N.S & $p=0.001$ & $p=0.001$ & $p=0.001$ & $p=0.001$ & $p=0.001$ \\
\hline p13 & $X^{2}=14.5332, d f=3, p=0.002262$ & N.S & N.S & $p=0.01$ & N.S & $p=0.01$ & N.S \\
\hline $\mathrm{p} 14$ & $X^{2}=92.0405, d f=3, p<2.2 e-16$ & $p=0.01$ & $p=0.001$ & $p=0.001$ & $p=0.05$ & $p=0.001$ & $p=0.001$ \\
\hline p15 & $X^{2}=55.2756, d f=3, p=5.997 e-12$ & $p=0.05$ & $p=0.001$ & $p=0.01$ & $p=0.001$ & N.S & $p=0.001$ \\
\hline $\mathrm{p} 16$ & $X^{2}=146.472, d f=3, p<2.2 e-16$ & N.S & $p=0.001$ & $p=0.001$ & $p=0.01$ & $p=0.001$ & $p=0.001$ \\
\hline p17 & $X^{2}=140.5225, d f=3, p<2.2 e-16$ & N.S & $p=0.001$ & $p=0.001$ & $p=0.01$ & $p=0.001$ & $p=0.001$ \\
\hline $\mathrm{p} 18$ & $X^{2}=21.9075, d f=3, p=6.819 e-05$ & N.S & N.S & $p=0.001$ & N.S & $p=0.01$ & N.S \\
\hline p19 & $X^{2}=98.4494, d f=3, p<2.2 e-16$ & $p=0.05$ & N.S & $p=0.001$ & $p=0.05$ & $p=0.001$ & $p=0.001$ \\
\hline p20 & $X^{2}=7.2278, d f=3, p=0.06498$ & N.S & N.S & N.S & N.S & N.S & N.S \\
\hline $\mathrm{p} 21$ & $X^{2}=114.3282, d f=3, p<2.2 e-16$ & $p=0.001$ & N.S & $p=0.001$ & $p=0.001$ & N.S & $p=0.001$ \\
\hline $\mathrm{p} 22$ & $x^{2}=63.2816, d f=3, p=1.169 e-13$ & N.S & $p=0.001$ & $p=0.001$ & $p=0.001$ & $p=0.001$ & $p=0.001$ \\
\hline p23 & $X^{2}=79.0834, d f=3, p<2.2 e-16$ & $p=0.001$ & $p=0.01$ & $p=0.001$ & N.S & N.S & N.S \\
\hline p24 & $X^{2}=134.2695, d f=3, p<2.2 e-16$ & N.S & $p=0.001$ & $p=0.001$ & $p=0.001$ & $p=0.001$ & $p=0.001$ \\
\hline p25 & $X^{2}=56.1558, d f=3, p=3.891 e-12$ & N.S & $p=0.01$ & N.S & $p=0.001$ & $p=0.01$ & $p=0.05$ \\
\hline p26 & $X^{2}=35.8875, d f=3, p=7.91 e-08$ & $p=0.001$ & N.S & N.S & $p=0.01$ & $p=0.001$ & N.S \\
\hline $\mathrm{p} 27$ & $x^{2}=32.1362, d f=3, p=4.899 e-07$ & N.S & $p=0.01$ & $p=0.001$ & $p=0.05$ & $p=0.05$ & N.S \\
\hline p28 & $X^{2}=86.5888, d f=3, p<2.2 e-16$ & $p=0.001$ & N.S & $p=0.001$ & N.S & $p=0.001$ & $p=0.001$ \\
\hline p29 & $X^{2}=25.3108, d f=3, p=1.329 e-05$ & N.S & $p=0.001$ & N.S & $p=0.001$ & N.S & $p=0.001$ \\
\hline p30 & $X^{2}=94.0832, d f=3, p<2.2 e-16$ & $p=0.001$ & $p=0.001$ & N.S & $p=0.001$ & $p=0.001$ & $p=0.001$ \\
\hline p31 & $X^{2}=82.2795, d f=3, p<2.2 e-16$ & N.S & $p=0.001$ & $p=0.001$ & $p=0.001$ & $p=0.001$ & $p=0.001$ \\
\hline p32 & $X^{2}=132.0132, d f=3, p<2.2 e-16$ & $p=0.05$ & $p=0.001$ & $p=0.001$ & $p=0.001$ & $p=0.001$ & $p=0.001$ \\
\hline p33 & $X^{2}=107.1492, d f=3, p<2.2 e-16$ & N.S & $p=0.001$ & $p=0.001$ & $p=0.001$ & $p=0.001$ & $p=0.001$ \\
\hline p34 & $X^{2}=12.6864, d f=3, p=0.005366$ & $p=0.01$ & N.S & N.S & N.S & N.S & N.S \\
\hline p35 & $X^{2}=70.7854, d f=3, p=2.898 e-15$ & $p=0.001$ & $p=0.001$ & $p=0.01$ & $p=0.001$ & N.S & $p=0.001$ \\
\hline p36 & $X^{2}=27.8999, d f=3, p=3.812 e-06$ & N.S & N.S & $p=0.01$ & N.S & N.S & N.S \\
\hline p37 & $X^{2}=50.9824, d f=3, p=4.935 e-11$ & N.S & N.S & $p=0.001$ & N.S & $p=0.001$ & N.S \\
\hline p38 & $X^{2}=88.9472, d f=3, p<2.2 e-16$ & $p=0.001$ & $p=0.01$ & $p=0.01$ & $p=0.001$ & $p=0.01$ & $p=0.001$ \\
\hline p39 & $X^{2}=47.5966, d f=3, p=2.595 e-10$ & $p=0.001$ & $p=0.01$ & $p=0.001$ & N.S & N.S & N.S \\
\hline $\mathrm{p} 40$ & $X^{2}=94.4655, d f=3, p<2.2 e-16$ & N.S & N.S & $p=0.001$ & N.S & $p=0.001$ & $p=0.001$ \\
\hline $\mathrm{p} 41$ & $X^{2}=79.079, d f=3, p<2.2 e-16$ & $p=0.001$ & N.S & $p=0.01$ & $p=0.001$ & $p=0.001$ & N.S \\
\hline
\end{tabular}




\begin{tabular}{|c|c|c|c|c|c|c|c|}
\hline p42 & $X^{2}=23.715, d f=3, p=2.865 e-05$ & $p=0.01$ & N.S & N.S & $p=0.01$ & $p=0.001$ & N.S \\
\hline p43 & $X^{2}=86.0122, d f=3, p<2.2 e-16$ & N.S & $p=0.001$ & $p=0.001$ & $p=0.001$ & $p=0.001$ & $p=0.001$ \\
\hline p44 & $X^{2}=27.807, d f=3, p=3.987 e-06$ & N.S & $p=0.001$ & N.S & $p=0.001$ & N.S & $\mathrm{p}=0.001$ \\
\hline p45 & $X^{2}=53.2645, d f=3, p=1.61 e-11$ & N.S & $p=0.001$ & N.S & $p=0.001$ & $p=0.001$ & $p=0.01$ \\
\hline p46 & $X^{2}=31.2824, d f=3, p=7.413 e-07$ & N.S & $p=0.001$ & N.S & $p=0.001$ & N.S & $p=0.001$ \\
\hline p47 & $X^{2}=72.9925, d f=3, p=9.757 e-16$ & N.S & $p=0.001$ & N.S & $p=0.001$ & $p=0.001$ & $p=0.001$ \\
\hline p48 & $X^{2}=152.917, d f=3, p<2.2 e-16$ & $p=0.001$ & $p=0.001$ & $p=0.001$ & $p=0.001$ & $p=0.001$ & $p=0.01$ \\
\hline p49 & $X^{2}=63.6709, d f=3, p=9.652 e-14$ & N.S & N.S & $p=0.001$ & N.S & $p=0.001$ & $p=0.001$ \\
\hline p50 & $X^{2}=72.4929, d f=3, p=1.248 \mathrm{e}-15$ & $p=0.001$ & $p=0.001$ & $p=0.001$ & $p=0.01$ & $p=0.01$ & N.S \\
\hline p51 & $x^{2}=121.4764, d f=3, p<2.2 e-16$ & $p=0.01$ & $p=0.001$ & $p=0.001$ & $p=0.01$ & $p=0.001$ & $p=0.001$ \\
\hline p52 & $X^{2}=73.8372, d f=3, p=6.431 e-16$ & $p=0.01$ & $p=0.05$ & $p=0.001$ & N.S & $p=0.001$ & $p=0.001$ \\
\hline p53 & $X^{2}=58.9537, d f=3, p=9.834 e-13$ & $p=0.001$ & $p=0.001$ & N.S & $p=0.001$ & N.S & $p=0.001$ \\
\hline p54 & $X^{2}=28.7926, d f=3, p=2.476 e-06$ & N.S & $p=0.05$ & $p=0.01$ & N.S & $p=0.001$ & $p=0.001$ \\
\hline p55 & $X^{2}=75.3837, d f=3, p=2.998 e-16$ & N.S & N.S & $p=0.001$ & N.S & $p=0.001$ & $p=0.001$ \\
\hline p56 & $X^{2}=61.4547, d f=3, p=2.873 e-13$ & $p=0.001$ & N.S & N.S & $p=0.001$ & $p=0.001$ & N.S \\
\hline p57 & $X^{2}=40.9767, d f=3, p=6.614 e-09$ & N.S & $p=0.001$ & N.S & $p=0.001$ & $p=0.01$ & $p=0.001$ \\
\hline p58 & $X^{2}=72.5886, d f=3, p=1.191 e-15$ & N.S & $p=0.001$ & $\mathrm{p}=0.001$ & $p=0.001$ & $p=0.001$ & $p=0.001$ \\
\hline p59 & $X^{2}=96.7315, d f=3, p<2.2 e-16$ & $p=0.01$ & $p=0.001$ & $p=0.001$ & $p=0.001$ & $p=0.001$ & N.S \\
\hline p60 & $X^{2}=13.5855, d f=3, p=0.003527$ & $p=0.01$ & N.S & $\mathrm{p}=0.001$ & N.S & N.S & N.S \\
\hline p61 & $X^{2}=96.2835, d f=3, p<2.2 e-16$ & $p=0.001$ & $p=0.001$ & $\mathrm{p}=0.05$ & $p=0.05$ & $p=0.001$ & $p=0.001$ \\
\hline p62 & $x^{2}=31.5711, d f=3, p=6.444 e-07$ & N.S & $p=0.05$ & N.S & $p=0.001$ & N.S & $p=0.05$ \\
\hline p63 & $X^{2}=49.9463, d f=3, p=8.202 e-11$ & N.S & $p=0.001$ & N.S & $p=0.001$ & N.S & $p=0.001$ \\
\hline p64 & $X^{2}=21.9726, d f=3, p=6.609 e-05$ & N.S & $p=0.001$ & $p=0.05$ & $p=0.01$ & N.S & N.S \\
\hline p65 & $X^{2}=17.8008, d f=3, p=0.0004835$ & $p=0.001$ & N.S & N.S & N.S & N.S & N.S \\
\hline p66 & $x^{2}=78.504, d f=3, p<2.2 e-16$ & $p=0.001$ & $p=0.001$ & N.S & $p=0.01$ & $p=0.001$ & $p=0.001$ \\
\hline p67 & $X^{2}=40.1883, d f=3, p=9.719 e-09$ & N.S & $p=0.001$ & N.S & $p=0.001$ & N.S & $p=0.001$ \\
\hline p68 & $X^{2}=15.8611, d f=3, p=0.001211$ & N.S & N.S & $p=0.01$ & N.S & N.S & $p=0.01$ \\
\hline p69 & $X^{2}=45.4726, d f=3, p=7.342 e-10$ & $p=0.001$ & $p=0.001$ & N.S & $p=0.01$ & $p=0.01$ & $p=0.001$ \\
\hline p70 & $X^{2}=36.0571, d f=3, p=7.283 e-08$ & N.S & $p=0.001$ & N.S & $p=0.001$ & N.S & $p=0.001$ \\
\hline p71 & $X^{2}=34.6872, d f=3, p=1.418 e-07$ & $p=0.001$ & N.S & N.S & $p=0.01$ & $p=0.001$ & N.S \\
\hline pQ1 & $X^{2}=243.6771, d f=3, p<2.2 e-16$ & N.S & $p=0.001$ & N.S & $p=0.001$ & N.S & $p=0.001$ \\
\hline pQ2 & $X^{2}=243.6771, d f=3, p<2.2 e-16$ & N.S & $p=0.001$ & N.S & $p=0.001$ & N.S & $p=0.001$ \\
\hline pQ3 & $X^{2}=243.6771, d f=3, p<2.2 e-16$ & N.S & $p=0.001$ & N.S & $p=0.001$ & N.S & $p=0.001$ \\
\hline pQ4 & $X^{2}=243.6771, d f=3, p<2.2 e-16$ & N.S & $p=0.001$ & N.S & $p=0.001$ & N.S & $p=0.001$ \\
\hline
\end{tabular}


Figure 1
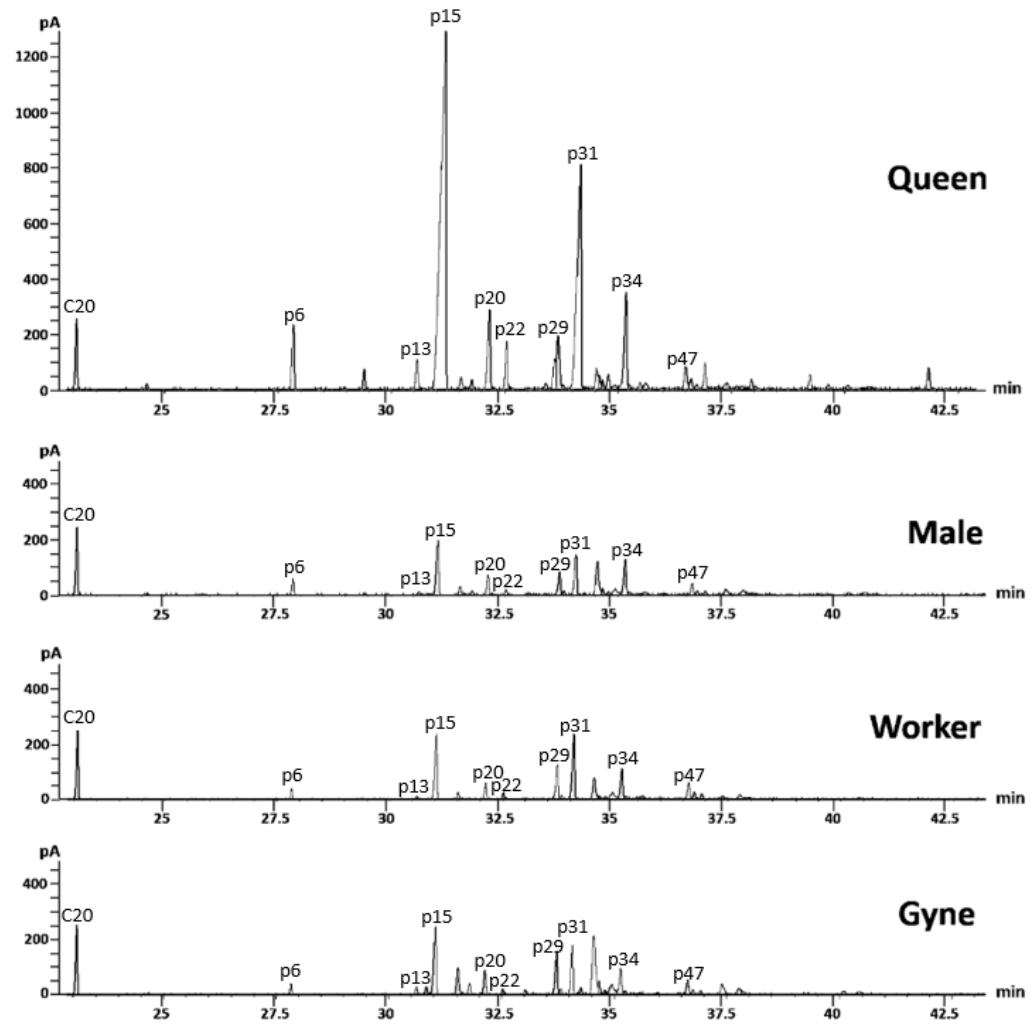

517

517 
Figure 2

Ligueil B (PCA)

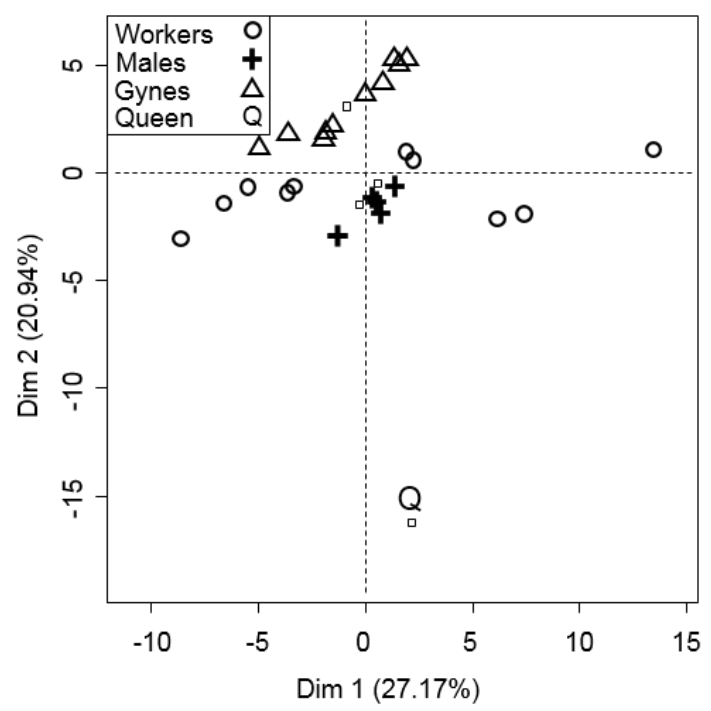

Ligueil C (PCA)

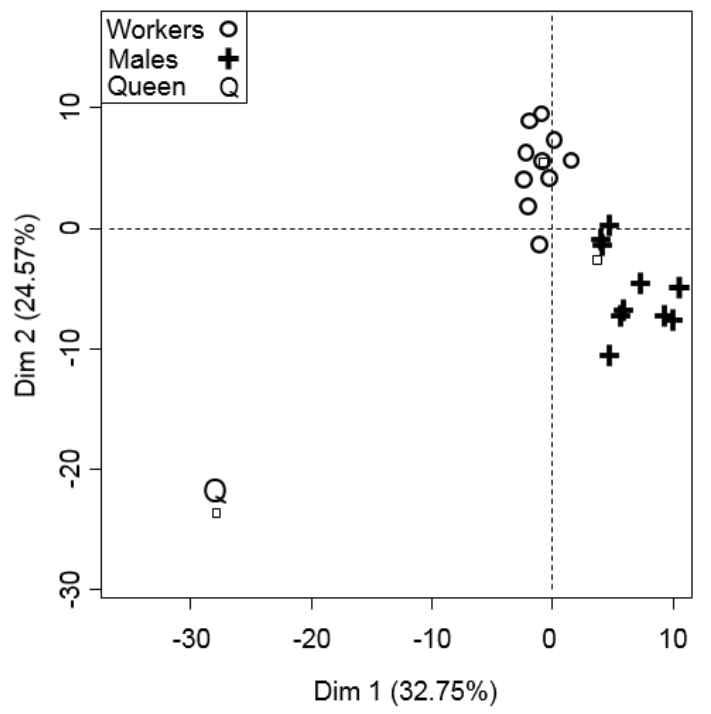

Montlouis (PCA)

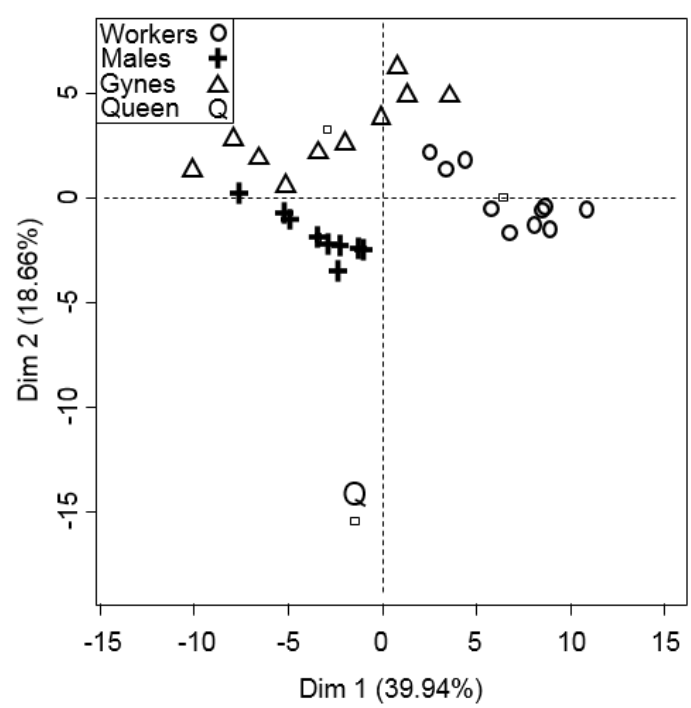

St Avertin (PCA)

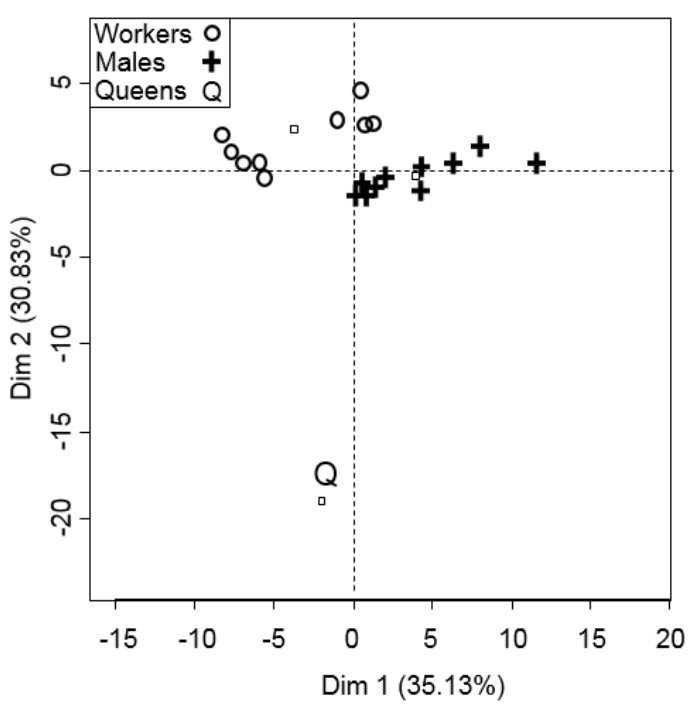


Figure 3
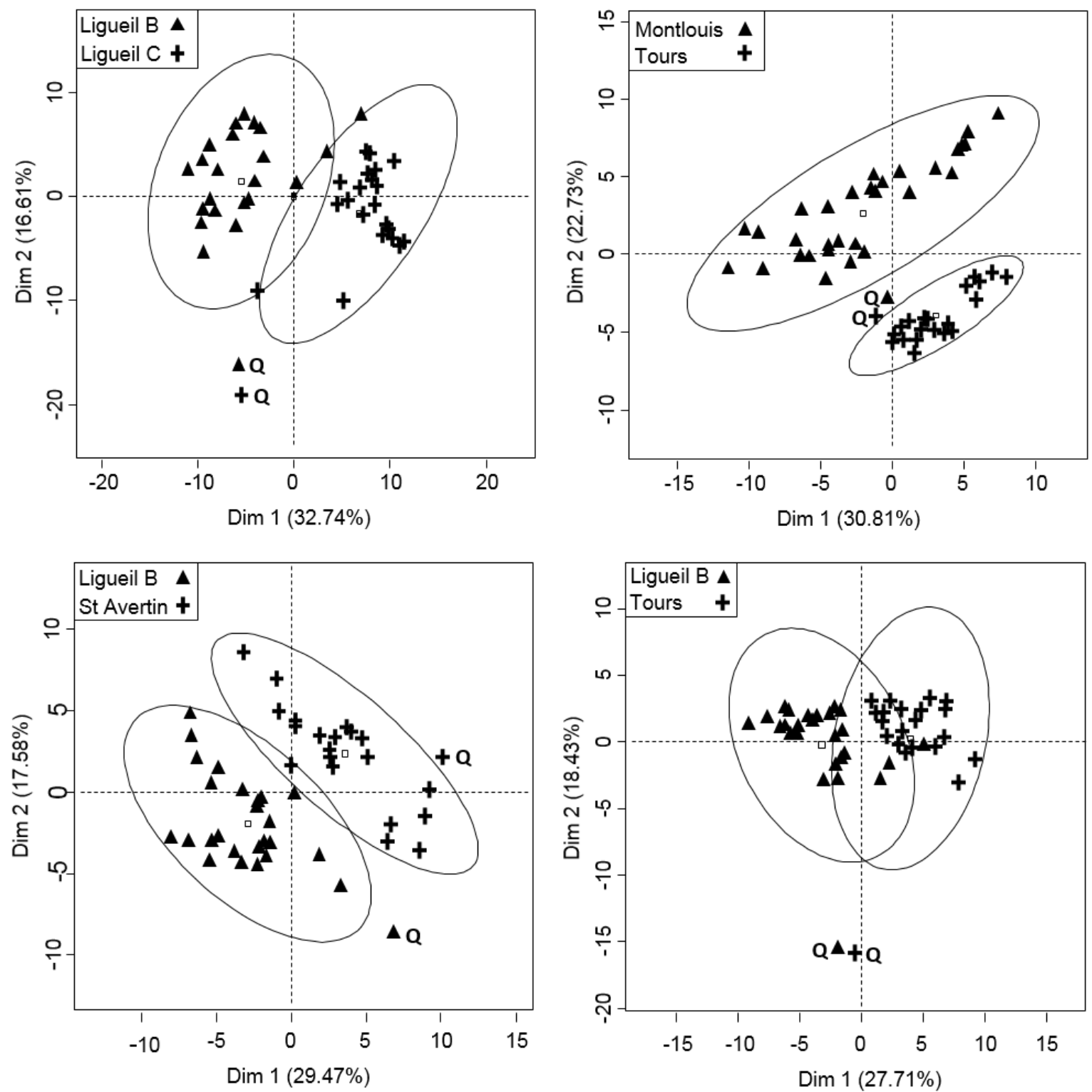

526

527

528

529

530

531

532

533

534

535 

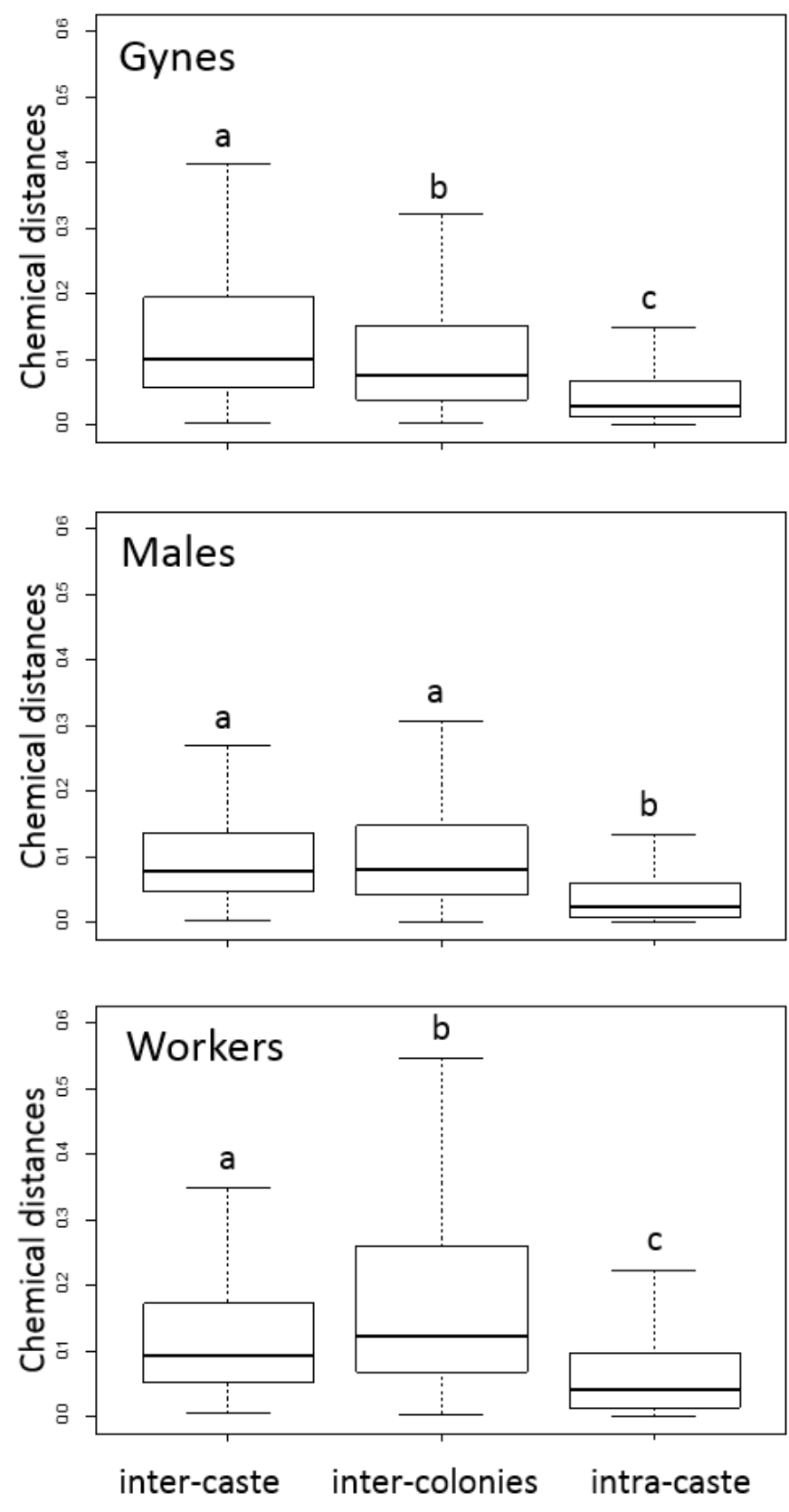

537

538 
Figure 5

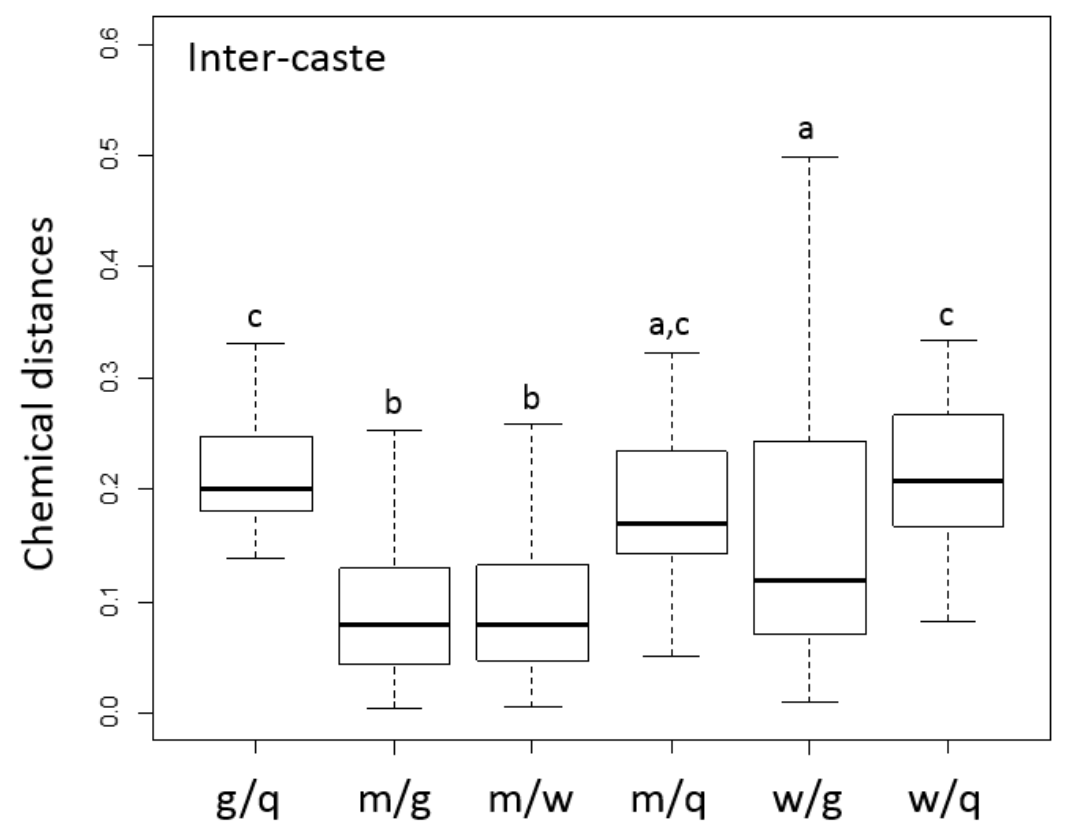

540 
Figure 6

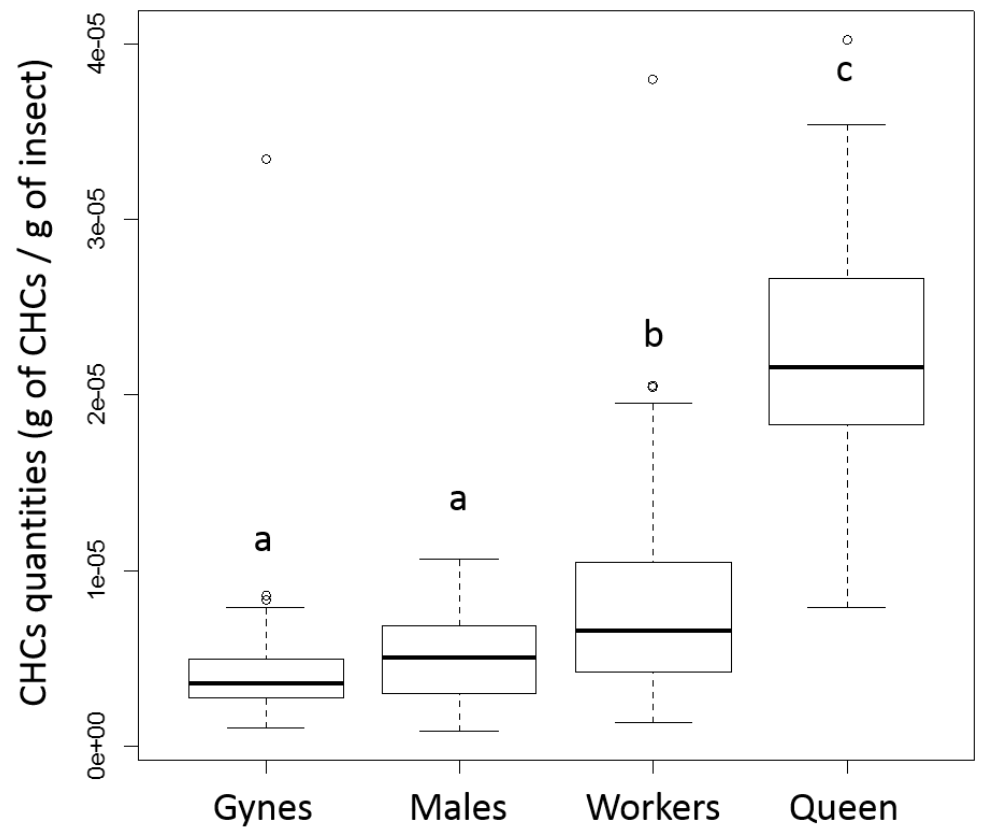

543

544

545

546

547

548

549 
Figure 7
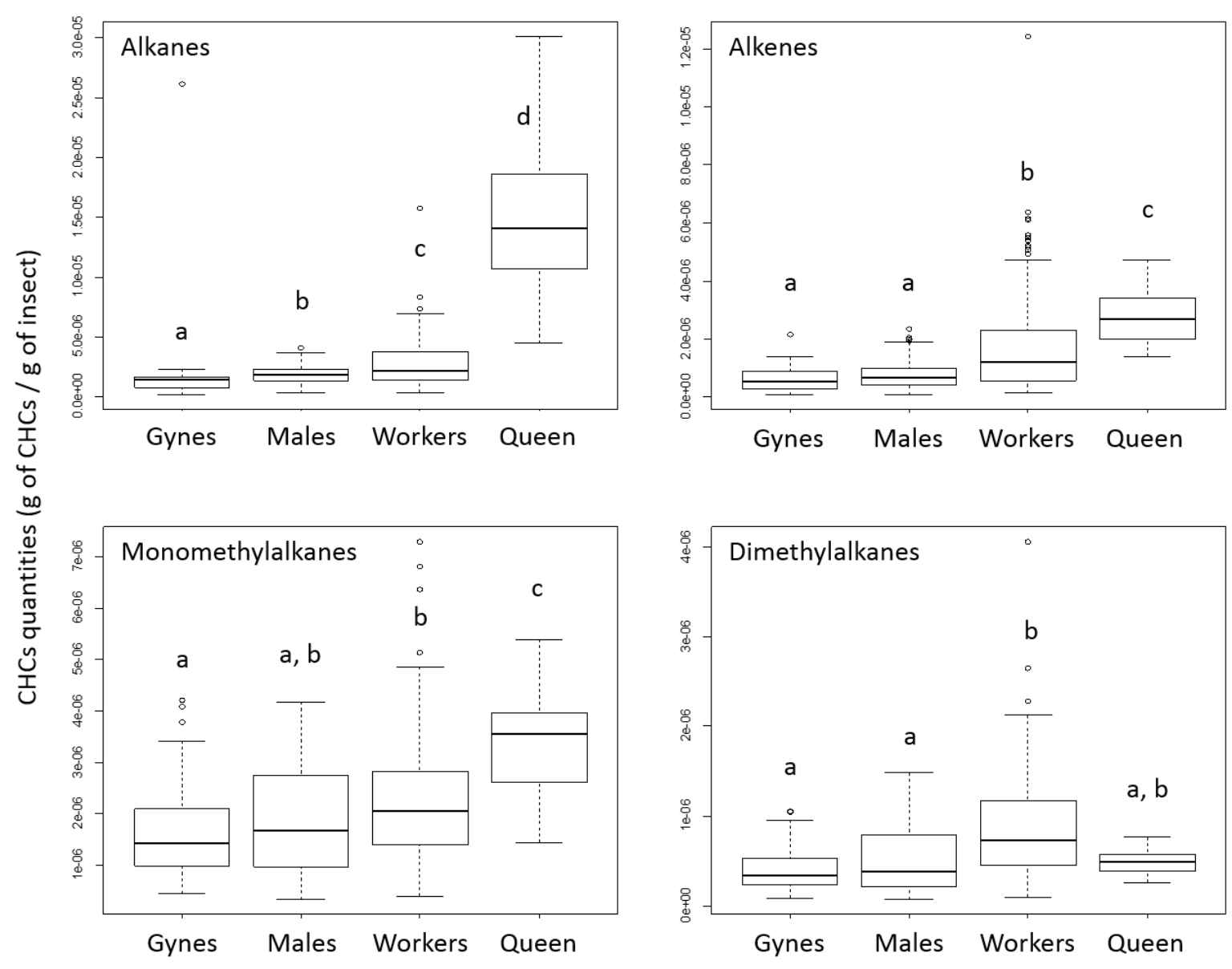

551

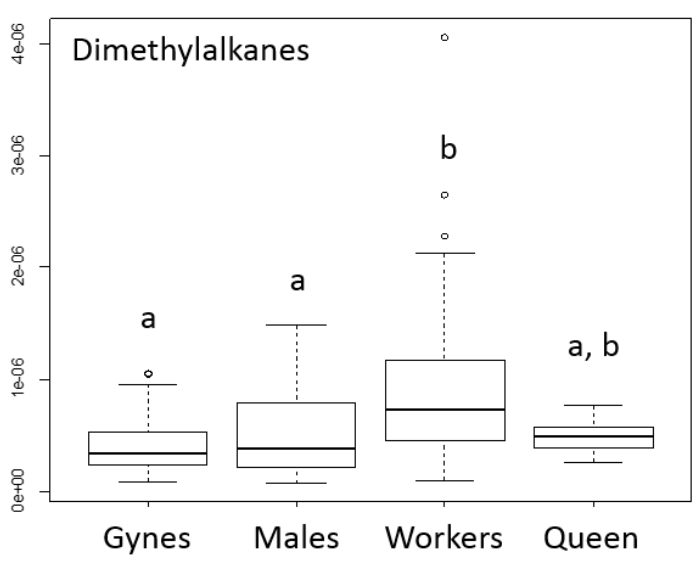

